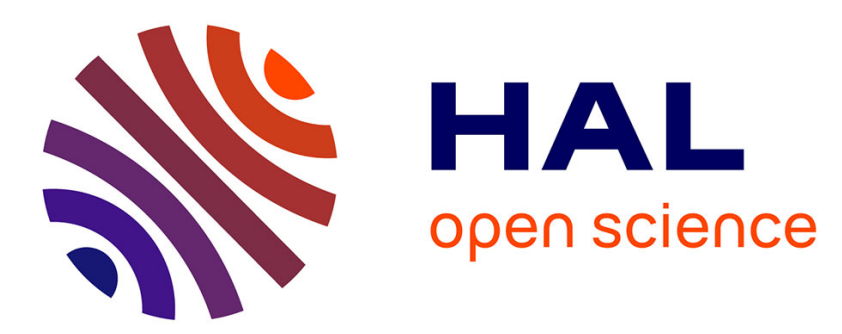

\title{
Current frontiers and recommendations for the study of microplastics in seafood
}

\author{
Alexandre Dehaut, Ludovic Hermabessiere, Guillaume Duflos
}

\section{To cite this version:}

Alexandre Dehaut, Ludovic Hermabessiere, Guillaume Duflos. Current frontiers and recommendations for the study of microplastics in seafood. Trends in Analytical Chemistry, 2019, 116, pp.346-359. 10.1016/j.trac.2018.11.011 . anses-02558719

\section{HAL Id: anses-02558719}

\section{https://hal-anses.archives-ouvertes.fr/anses-02558719}

Submitted on 25 Oct 2021

HAL is a multi-disciplinary open access archive for the deposit and dissemination of scientific research documents, whether they are published or not. The documents may come from teaching and research institutions in France or abroad, or from public or private research centers.
L'archive ouverte pluridisciplinaire HAL, est destinée au dépôt et à la diffusion de documents scientifiques de niveau recherche, publiés ou non, émanant des établissements d'enseignement et de recherche français ou étrangers, des laboratoires publics ou privés.

\section{(ㄷ)(1) $\$$}

Distributed under a Creative Commons Attribution - NonCommerciall 4.0 International 
Version of Record: https://www.sciencedirect.com/science/article/pii/S0165993618305089

Manuscript_flb4fc36e66c32ed00257e9dad0afaa0

\section{Title}

2 Current frontiers and recommendations for the study of microplastics in seafood

\section{Authors}

4 Alexandre Dehaut*, Ludovic Hermabessiere \& Guillaume Duflos

\section{$5 \quad$ Affiliations}

6 ANSES - Laboratoire de Sécurité des Aliments, Boulevard du Bassin Napoléon, 62200 Boulogne-sur-

7 Mer, France.

8 *Corresponding Author: Alexandre Dehaut - alexandre.dehaut@ anses.fr

\section{ORCID:}

10 Alexandre Dehaut: 0000-0001-5377-995X

11 Ludovic Hermabessiere: 0000-0002-6775-2480

12 Guillaume Duflos: 0000-0003-2820-4411

1 on 33

(C) 2018 published by Elsevier. This manuscript is made available under the CC BY NC user license https://creativecommons.org/licenses/by-nc/4.0/ 


\section{Abstract}

14 For seventy years, mass plastic production and waste mismanagement have resulted in huge pollution of

15 the environment, including the marine environment. The first mention of seafood contaminated by microplastics was recorded in the seventies, and to date numerous studies have been carried out on shellfish, fish and crustaceans. Based on an ad hoc corpus, the current review aims to report on the numerous practices and methodologies described so far. By examining multiple aspects including problems related to the definition of the term microplastic, contamination at the laboratory scale, sampling and isolation, and quantification and identification, the aim was to point out current limitations and the needs to improve and harmonise practices for future studies on microplastics in seafood. A final part is devoted to the minimum information for publication of microplastics studies (MIMS). Based on the aspects discussed, MIMS act as a starting point for harmonisation of analyses.

\section{Keywords}

Microplastics; fishery products; methods; limits; recommendations

Abbreviations

ATR: attenuated total reflection, DAC: digestion atmospheric control, FAC: filtration atmospheric control, FAO: Food and Agriculture Organization, FPA: focal plan array, FT-IR: Fourier-transform infrared, GESAMP: Group of Experts on the Scientific Aspects of Marine Environmental Protection, $\mathrm{H}_{2} \mathrm{O}_{2}$ : hydrogen peroxide, $\mathrm{HClO}_{4}$ : perchloric acid, $\mathrm{HNO}_{3}$ : nitric acid, $\mathrm{KOH}$ : potassium hydroxide, $\mathrm{LC}_{50}$ : lethal concentration 50\%, LD $\mathrm{L}_{50}$ : lethal dose 50\%, LOAEL: Lowest observed adverse effect level, MIMS: Minimum Information for publication of Microplastics Studies, MP: microplastic, MSFD: Marine Strategy Framework Directive, NaClO: sodium hypochlorite, NIC: negative identification control, NOAEL: No observed adverse effect level, O/SC: operator/solution control, OSPAR: Convention for the Protection of the Marine Environment of the North-East Atlantic, PCE: positive control of extraction, PIC: positive identification control, Py-GC/MS: pyrolysis coupled with gas chromatography and mass spectrometry, SAC: sampling atmospheric control 


\section{Introduction}

In 2016, global plastic production, excluding fibres, was estimated at 335 millions metric tons [1]. In less than a century, plastic has become an unavoidable material thanks to its diverse and convenient properties such as durability, resistance and lightweight. However, a major issue concerning plastic is waste management. Since 1950, a small amount of global production has been recycled (9\%), most often for a single cycle, while a huge quantity $(60 \%)$ has been discarded in the environment, and ultimately in the marine environment [2].

Consequently, vast quantities of plastic have accumulated in the oceans all around the globe, and these plastics are subject to degradation through various processes including UV degradation, oxidisation, and abrasion. The sizes of these pieces of plastics cover nearly 12 log scales from meter to nanometre [3], facilitating their ingestion by a wide range of marine organisms from the largest such as sperm whales [4] to the smallest, i.e. copepods [5]. Among all these synthetic particles, microplastics (MP) are commonly defined as plastic items with a size below $5 \mathrm{~mm} \mathrm{[6].}$

There are many questions surrounding the ecological and human health risks posed by MP. There have been few studies on the direct, for example physical effects of MP, or indirect harms caused either by bacteria or by chemicals. Concerning indirect harms, it has been demonstrated that MP are covered by numerous bacterial genera [7], including pathogenic and non-pathogenic Vibrio species [8]. MP are also a vector of hydrophobic organic compounds (HOC), but the actual risk is a subject of debate [9]. Finally, another suspected hazard is related to the presence of numerous additives in plastic that can make up $60 \%$ of the total weight [10], and that can leach out from the MP [11]. Bacterial and chemical hazards are thus more related to MP surfaces and volumes; the current definition of MP, solely based on length, therefore does not seem accurate enough for risk assessment.

Ingestion of microplastics has been described in numerous marine organisms, including different species of bivalves, crustaceans, cephalopods and fish [12-75]. The number of studies on MP-contaminated seafood has increased exponentially, but there is still no standardised methodology, making it impossible to compare studies. This is a major issue in terms of assessing the risk(s) posed by MP. As a way to 
improve and harmonise methods for the future studies, the different steps of MP analysis: sampling, isolation, quantification, polymer identification, and contamination management were analysed and compared based on the available literature. For the period from 1973 to April 2018, 64 studies published were gathered from Scopus and PubMed, based on their main subject dealing with both microplastics and seafood. These publications were analysed using an $a d$ hoc reading grid. This corpus comprises 3 articles published before 2010 [12-14], 5 between 2010 and 2012 [15-19], 7 between 2012 and 2014 [20-26], 12 between 2014 and 2016 [27-38], and 37 between 2016 and 2018 [39-75].

\section{Definition and size issues}

\subsection{Current definitions and limits}

As previously mentioned, the term microplastic historically refers to "plastic particles smaller than 5 $\mathrm{mm}$ " as stated by the international research workshop on the occurrence, effects, and fate of microplastic marine debris [6]. Moreover, this definition is taken up by several international bodies such as the Group of Experts on the Scientific Aspects of Marine Environmental Protection (GESAMP) [76], the Food and Agriculture Organization (FAO) [77], the Convention for the Protection of the Marine Environment of the North-East Atlantic (OSPAR) [78], and the Marine Strategy Framework Directive (MSFD) [79]. Nonetheless, a minority of researchers prefer to define microplastics as particles with a size $<1 \mathrm{~mm}$ [80]. Although the upper limit is well established, its counterpart, i.e. the lower limit, is more subject to debate, with different limits being considered: $20 \mu \mathrm{m}$ and $5 \mu \mathrm{m}$ [78], $1 \mu \mathrm{m}$ [81] and $100 \mathrm{~nm}$ [82]. Historically, the limit of $100 \mathrm{~nm}$ was established based on the definition of nanomaterials. However, nanoplastics result from the degradation of larger pieces and are thus not intentionally produced [81]. Their heterogeneous characteristics such as size distribution, shape, surface charges, stability, ability to form aggregates and porosity, call into question the limit of $100 \mathrm{~nm}$ [81].

\subsection{Limitations of current definitions and proposals for improvement}

More generally, as discussed in the review carried out by Monserrat Filella [83], it is problematic to retain a definition solely based on a size corresponding to the "largest part of the particle". This 
definition is not sufficiently clear and is not suitable for the current challenges in environmental and human toxicological risk assessment [84]. Moreover, it has been highlighted that regarding particle sizes and shapes, differences in toxicity are recorded [85]. These limits are illustrated in the first half of Table 1. Three particles namely a cube, sphere and fibre measuring $5 \mathrm{~mm}$ at the largest part of one of their dimensions are proposed. The cube has a 4-log scale higher volume compared to the fibre. Similarly, when equal volumes are considered, in the second half of Table 1, the surface area of the fibre is 2-log scale larger than that of the cube. Due to their morphology, there are considerable differences between cubes and spheres on the one hand, and fibres on the other. Cubes and spheres are characterised by large volumes, while fibres have very small volumes but large surfaces of contact. The need for a "threedimensional" definition is also echoed in recent studies [86-88]. Indeed, these dimensions will be helpful to estimate particles weights, depending on polymer types. Weight estimates are requested by scientists based for different reasons: 1) because plastic inputs in ocean are usually expressed in metric tons, and 2) because identification technology using mass spectrometry, such as pyrolysis coupled with gas chromatography and mass spectrometry (Py-GC/MS), processes signals related to analytes mass. Likewise, having an estimate of particle weights coupled with identification of the polymer would be helpful for toxicological approaches. Clearly, the main toxicological dose descriptors, such as the no observed adverse effect level (NOAEL), lowest observed adverse effect level (LOAEL), lethal dose $50 \%\left(\mathrm{LD}_{50}\right)$ or lethal concentration $50 \%\left(\mathrm{LC}_{50}\right)$, are usually expressed as a mass $(\mathrm{mg})$ per mass $(\mathrm{kg}$ bw, $\mathrm{kg}$ ) or volume (L) per duration (day or hours).

\section{TABLE 1 goes here (if possible)}

This raises the question of how to measure these three dimensions. Some commercial devices propose these expensive configurations, but they usually require a perfectly flat background to serve as a

111 reference of measurement, which is usually not encountered with filters containing MP. Alternative strategies could be used to approximate the volume, such as considering particles as an ellipsoid [86] and using polymer average densities, to estimate particles mass. In this way, authors could propose the contribution of each polymer type to the total mass of MP [86]. The same authors explain that a single 
115 polypropylene MP, with an estimated weight of $4.4 \mu \mathrm{g}$, contributes highly to the total mass of the

116 isolated particles. Hermabessiere et al. [87] used a similar approach with pristine MP. It was shown that

117 the volume of microspheres and fibres can be estimated easily by equating them with perfect spheres

118 and cylinders. There are strong concerns regarding fragments with irregular shapes, mostly secondary

119 MP, which probably constitute the largest proportion of MP and are of great concern for the MP

120 community [89]. Here again, approximations can be suggested, such as calculating a mean diameter,

121 assuming that the shape factor of the particle $\left(4 \pi \times\left(\frac{\text { area }}{\text { perimeter }}\right)^{2}\right)$ is not significantly less than 1 [83].

122 Among other approximations, Simon et al. [86] proposed to approximate the thickness of the particle.

123 They considered that the ratio linking thickness to the minor dimension of the particle is the same as the

124 average ratio between minor and major dimensions. The average ratio was calculated from the ratios

125 measured for the whole analysed particle. Finally, the particle depth could also be estimated using an

126 ocular micrometre as proposed by Davison \& Asch [17], but this would require particle handling which

127 does not meet the current challenges.

128 Based on these facts, there is a need for the research community working on MP, not only those working 129 on seafood, to reassess the definition of a MP, as the meaning of this term is not the same for everyone.

130 The mass of MP or at least the tri-dimensional structure and the shape of MP have to be considered. As a

131 basis for any study on MP and as the first main element of standardisation this new definition,

132 incorporating lower and upper limits, should be adopted by all scientists.

133 3. Laboratory environment and prevention of contamination

134 Microparticles of plastic are ubiquitous and can be collected everywhere in the laboratory environment 135 or on operators (Figure 1). Each type of MP can be found, from fibres that are highly represented, to 136 fragments. 
The low number of particles in the analysed samples makes the presence of these microparticles in the surrounding environment more than problematic. There is a clear risk of overestimating MP loads in samples, leading to poorly robust results [53].

141 Based on the corpus (Table 2), the external environment and the prevention of contamination were assessed regarding different parameters such as the operator, the work environment and cleaning procedures, and preparation of solutions, blanks and their management.

\subsection{Contamination from the operator}

145

With regard to prevention of contamination by the operator, only $36 \%$ of the studies reported that the operators wore cotton lab coats. Nonetheless, behind this overall statistic, it should be noted that proportions are evolving. Since the first mention of cotton lab coat in a publication in 2014 [29], the number of publications has increased each year and, in $2018,58 \%$ of publications $(n=12)$ clearly specified its use $[64,65,67,68,71,74,75]$. Some interesting additional pieces of information were provided by two studies. The first, mentioned by Bråte et al. [40], indicates that cotton lab coats were cleaned with a sticky roller. This detail could be important bearing in mind that lab coats can be cleaned either at industrial or local laboratory laundries. In the cleaning machines, lab coats can be mixed with other kinds of fabrics with possible synthetic fibre transfer. The second idea, developed by Kühn et al. [67], is the use of coloured cotton lab coats. This would help scientists to systematically exclude a given type of coloured fibre. However, the colour choice has to be oriented towards the less encountered colours, which is not always easy. Prevention of contamination by the operator could also be considered through the use of gloves, as operators' fingers can carry fibres (Figure 1 B). Overall, $20 \%$ of the corpus articles (Table 2) clearly mentioned that gloves were worn. Here again, these practices tend to be more widespread than a few of year. Wearing gloves has two advantages: contamination prevention and operator protection from harmful chemical products that can be used to destroy biological tissues (see 4.3). Special care should be taken to ensure that no MP are present at the surface of gloves by keeping them in a protected box, and cleaning them using filtered water/alcohol solutions or compressed air. 
164 Considering the work environment, two parameters should be considered: the place where samples are 165 handled, and the tools, materials and equipment used to carry out the experiments. Cleaning procedures are more or less well described in the publications. In all, $61 \%$ of the corpus (Table 2) has an explicit mention of this procedure, with this percentage rising to $80 \%$ for the two last years $(n=25)$. Cleaning procedures are highly diverse, but $87 \%$ of them involve the use of liquid rinsing. The solution or chemicals used for this step are water (tap, deionised, purified, ultrapure, MilliQ), alcohol (either not defined or ethanol) and acetone. In $35 \%$ of these procedures, a combination of solutions or replication of rinsing with three successive rinsing steps are used. In five studies, cleaning was followed by control under a stereomicroscope $[43,46,52,65,67]$. Only four studies performed solely a stereomicroscope check, without a rinsing procedure $[26,44,54,55]$. Finally, a single work used glassware heat treatment by heating glass at $550^{\circ} \mathrm{C}$ for $4 \mathrm{H}$ before its use [48]. Unfortunately, heating glassware is only feasible for small containers, while, due to samples sizes, large volumes of solution can be required for the digestion of tissues.

As previously mentioned, the place where handling is carried out should also be considered to avoid airborne MP contamination. In a recent study, Wesh et al. proposed a comparison between different working environments, including a basic laboratory bench, a car in-house laboratory facility, a fumehood and a clean bench, i.e. laminar flow or safety cabinet [90]. Their results showed that the clean bench significantly reduced the number of contaminated samples compared with the other three devices ( $p$-value $<0.01$ ). The use of such devices should therefore be encouraged strongly as a standard practice for the analysis of MP in seafood. A special care would have to be paid to the filters in such devices. Like for microbiological purposes, HEPA H14 $0.3 \mu \mathrm{m}$ filters should be considered as the minimum standard because, based on EN 1822-1, these have an efficiency of $99.995 \%$ for particles $>0.3 \mu \mathrm{m}$. Considering studies using chemical products and for safety reasons, addition of an activated carbon filter should be recommended for air expelled into the room. The use of horizontal airflow cabinets should be avoided to protect operators from hazardous vapours emanating from digestates. Regarding the corpus 
189 (Table 2), since 2017, 61\% of the articles did not clearly describe a specific place for carrying out 190 analyses, and more than half of the studies still do not described a way of preventing contamination in

191 the working area. This fact raises concerns regarding the levels of MP contamination reported in the literature. Concerning studies that used strategies to prevent contamination of the work place, only $12.5 \%(\mathrm{n}=8)$ mentioned the use, even partially, of a type of airflow cabinet during the study on microplastics in samples $[23,29,31,32,51,53,60,75]$. The other most commonly used work areas are basic cleaned laboratory benches $(10.9 \% ; n=7)[26,44,45,55,57,68,72]$ and fume hoods $(10.9 \% ; n=7)$ $[27,30,32,38,41,47,63]$. A single study reported the use of both a fume hood and laminar flow cabinet [32]. Three studies (4.7\%) indicated that analyses were performed in specific laboratories, with controlled circulation $[40,52,64]$. Finally, one study even used an infant incubator to process samples [58], which can be considered as a highly protected environment under reserve of sealing the place where the arms come through.

\subsection{Contamination from used solutions}

202 Although an essential parameter, the filtration of solutions is mostly not mentioned in publications, as $75 \%$ of the corpus (Table 2) did not specify any filtration of the solutions used, even when chemical approaches were employed to digest tissues. Despite this figure, it should be noted that half of the experiments using filtered solutions were reported in studies published since 2017. In fact, even the use of "deionised, purified, ultrapure, MilliQ" water could be subject to recontamination after water circulation through the filter, membrane and resin. Filtration of solutions, as well as stereomicroscopic control of used filters, are mandatory for MP studies.

There is a real need for an "MP-free" standard for researchers in the field, like what has been developed in molecular biology with the "DNase-free" standard. This call for an "MP-free" standard relates on a broad of range of materials used for MP studies such as solutions, filters, gloves, etc. Unfortunately, laboratory suppliers are not familiar with the topic of MP, and efforts are needed to raise awareness of the analytical constraints involved in microplastics research. These MP-free materials would certainly be more expensive compared to current prices, but they would clearly offer non-negligible efficiency gains. 
216 The last point, concerning contamination prevention, is the use of controls, also referred to as blanks in

217 the publications. Controls aim to ascertain the quantity of MP coming from different sources of 218 contamination; therefore, different types of controls can be used in the studies. They are required whenever analysed tissues are in direct contact with external contamination sources. The main control usually employed in studies is covered by the catch-all term "procedural" blank; the second mentioned term is atmosphere control, and finally the last term is observational control. These controls respectively rely on controls that follow the same process than used for samples, control checking for potential contamination from the ambient air, and lastly is a specific control of ambient air during MP isolation into samples or onto filters. These terms could also refer to different controls at different steps of the analytical process.

There is a lack of precision and description of controls in the publications; the corpus was only studied based on "procedural", "atmosphere" and "observational" controls (Table 2). Before 2014, there is no mention of blanks or controls. Since 2014 , although $73.5 \%$ of articles mention a procedural blank, only $18.4 \%$ and $10.2 \%$ noted the use of atmosphere and observational controls, respectively. A few publications also propose new controls, namely positive/negative controls $[42,53]$ or control of sample containers [71]. Positive controls aim to check whether plastic present in samples is accurately recovered during the isolation process, whereas negative controls are more difficult to implement, as no MP-free matrix exists. The number of controls reported in the different studies can vary, and there is no clear statement on the appropriate number of controls to be performed. Some publications suggest applying controls to each analysed batch of samples [27, 32, 40], which might be encouraged for future standardisation. Nonetheless, overall the number of controls should not be too high compared with samples.

The first step concerned by control is dissection. This step is mostly subject to contamination by the atmosphere, tools and operator. The main problem at this step concerns the atmosphere, which is why the use of sampling atmospheric control (SAC) is highly encouraged. The second step, if applied, relates 
241 to digestion. It involves possible contamination by the atmosphere, operator and used solutions, and is 242 usually assessed by processing an Erlenmeyer flask without sample, as a flask containing a sample. For 243 this step, two controls can be proposed: a digestion atmospheric control (DAC) to monitor the 244 atmosphere, and a flask that undergoes the same analysis process as a sample, which can be considered an operator/solution control (O/SC). As proposed in a few studies [17, 42, 53], the use of a positive control of extraction (PCE), a flask with a defined number of MP, should be considered in future research. The third step consists in filtration with a risk of contamination by operators and the atmosphere; this risk can be assessed using a filtration atmospheric control (FAC). Finally, the observation step is mostly threatened with contamination by the atmosphere and tools, but most often, filters are protected by the lids of Petri dishes.

251 Although controls are often referred in scientific studies, there are issues regarding their management and the communication of control results. As an example, since $2014,49 \%$ of the publications did not clearly report how controls results were managed, and only $32.7 \%$ of papers reported their blank results. These figures are not surprising as there is no consensus on this topic. Some strategies are not satisfactory as they use systematic exclusion of items, without considering the numbers found in controls vs. those observed in samples. Particles are thus subtracted without considering their colours or shapes, or an average number of particles counted in controls is subtracted. In some studies, it is reported that no particles were observed in the blanks. Based on all the studies analysed in this review, and bearing in mind the environment in which MP analysis is performed, it is justifiable to wonder about the accuracy of these control results. In contrast, the currently most advanced and thorough methodology consists in subtracting control counts, taking particle shape, colour, and synthetic nature into account $[46,72]$. This idea could also be combined with other approaches where the notion of control size and contact surface are highlighted $[48,52]$. This would help to compare controls and samples if the exposed surface is not the same. Finally, the notion of exposure time could also be taken into account [73] as controls are not always in contact with the atmosphere for a period equivalent to that of the samples. By combining all these ideas, future controls could be expressed as number of items $\mathrm{cm}^{-2} \mathrm{~h}^{-1}$. This would enable researchers to accurately subtract items from sampled based on shape and 
colour of items, taking into account the surface and exposure time. The scientific community therefore needs to develop new approaches to reach a consensus on how to handle these important issues, and accurately estimate MP loads in seafood.

\subsection{Proposals for standardisation}

As explained above, preventing contamination in the context of MP analysis is a key factor from the arrival of samples at the laboratory to the reporting of results. Numerous parameters must be managed to perform MP analysis with good quality assurance and good laboratory practices.

Contamination from the operator must be reduced through the use of cotton lab coats and gloves. Concerning the work environment, the use of laminar flow cabinets is strongly encouraged [90]. This has to be accompanied by a cleaning procedure. All solutions used during MP analysis must be filtered to ensure the absence of particles. As contamination cannot be $100 \%$ ruled out, the use of different controls is mandatory. These approaches aim to monitor different types of contamination (atmosphere, operator, chemicals) and have to be thoroughly described in publications, together with the way they are incorporated into results.

Some gaps are still seen in published studies, but recent research tends to include improved measures to control contamination. This can be observed when regarding the specific "controls" or "quality assurance-quality control" paragraphs in the materials and methods sections of articles [53, 62, 72]. Figure 2 below illustrates the various parameters that should be applied by scientists for future research on MP in seafood.

\section{FIGURE 2 goes here (if possible)}

\section{Sampling and isolation}

\subsection{Sampling for studies on MP in seafood}

Sampling is the first step in the process for MP analysis. Preliminary essential data to record in publications are the number of individuals sampled and their scientific names. Overall, these data are suitably presented by authors, as only $7.8 \%$ of studies in the corpus (Table 2) did not explicitly report the 
number of individuals. A minimum of $n=50$ individuals has been defined by OSPAR and the MSFD as a

294 limit to obtain adequate sampling [78, 79], although MSFD members recognised that data on variability

295 related to sampling sizes are lacking. It should be noted that this number is not always respected in

296 studies.

297 Certain localisation parameters should also be recorded such as GPS coordinates, catching depths and types of capture (trawl type, mesh size, etc.). These data are easily recovered for scientific catches [26, 51, 67], but this could be more difficult when samples are purchased directly from fishermen or market or sold as processed seafood $[35,60,75]$.

When individuals are still whole, biometric data have to be recorded, such as total or standard length with an ichthyometer or a calliper and weight. Recording whole sample size will help scientists to determine whether this corresponds to a commercial size; as an example, commercial sizes for major European species can be found in Regulation (EC) No 850/98 [91]. Moreover, it could help to estimate the physiological state of studied organisms. Studies on bivalves and crustaceans usually meet this standard, but it is more difficult to find such studies on fish. However, these data are important, especially for risk assessments related to human health. On the basis of the corpus, $64.1 \%$ and $42.2 \%$ of papers (Table 2) mentioned average size and weight for whole or tissue samples, respectively, which is not satisfactory even in recent years. Less than half of the studies report weights, not always mentioning the one of analysed tissue. Improving these figures is therefore a major challenge for the coming years, particularly when the isolation step involves, as explained below, chemical digestion of tissues that needs to be standardised.

313 Sample management differs between studies; some research involves direct sampling of tissues on 314 board, while other studies preserve whole organisms until analysis. The procedure for tissue sampling 315 has also to be reported in studies as it could lead to additional contamination of samples, the use of SAC should be encouraged. During tissue recovery, recording the time of sample exposure to ambient air

317 would be an interesting parameter to record. It is especially important if the time factor is taken into 318 account by the controls (see 3.4). Moreover, it is important to rinse parts that are not analysed either for 
319 fish or bivalves as much as possible, so that contamination from other parts of the animal would not occur $[27,53]$.

\subsection{Tissue preservation before processing}

322 There are two methods for storing samples: storage at temperatures below $0{ }^{\circ} \mathrm{C}$, i.e. samples placed in a freezer, or at temperatures above $0^{\circ} \mathrm{C}$ in chemical mixtures, e.g. formaldehyde and ethanol. These data must also be reported in scientific papers as they could have an impact on the observed results. Together with the method used to preserve samples, the storage time would be of interest, even though it is not essential. To the best of authors knowledge, a single study looked at the impact of preservation methods on microplastics [52], comparing storage at $-20^{\circ} \mathrm{C}$ for ten days to storage in $4 \%$ formaldehyde for three days. No effect of the storage method was found by the researchers. Unfortunately, except for two studies that used same concentrations of formaldehyde $[18,67]$, the others used a concentration of $5 \%$ or higher $[15,17,51,65,68]$. Likewise, a storage limited to three days in formaldehyde seems to be inconsistent with scientific fishing campaigns that can last weeks [92, 93], with long periods before samples landing. Nonetheless, this type of approach aiming to assess the impact of sample processing on MP integrity is of great interest and should be pursued. Another important area of study is the compatibility of solutions used during samples processing. In the case of formaldehyde, the use of oxidising chemicals or perchloric acid downstream should be prohibited due to the potential development of violent reactions. This shows that sample storage should be taken into account as soon as the study is designed. When possible, sample freezing should be given preference, particularly when chemical digestion is performed downstream. It has been well documented, particularly in fish, that freezing has an impact on muscle constituents. On the one hand, mechanical destruction of tissue can occur due to crystallisation of certain water pools inside muscle, and on the other, protein aggregation and lipid oxidisation can occur [94]. These phenomena are all the more likely when freezing kinetics are slow, the freezing time is long, and the freezing temperature is low. Here again, long periods of freezing can occur between sampling and analysis, and it would be of great value to assess whether long freezing 
times are an advantage or a disadvantage for both dissection and chemical degradation of seafood tissues.

TABLE 2 goes here (if possible)

\subsection{Dissection and digestion methods for MP studies}

348 At this point in the analysis process, there are two main methodologies: dissection and chemical digestion of tissues. Consulting the corpus (Table 2), a trend is emerging, whereby small sampling quantities are more often subject to the chemical approach: $66 \%$ of studies $(n=29)$ with sampling $\leq 180$ individuals used such an approach. In contrast, $62 \%$ of studies $(n=29)$ with sampling $>180$ individuals prefer the dissection approach. Methodology can also be governed by the type of studied organism, as an example bivalves are exclusively studied as a whole after a chemical digestion (Table 2).

Dissection is very easy to set up and implement, and it is not expensive. This could explain why it is generally preferred for MP studies, and particularly for very large sampling sizes. It accounts for more than half of the whole corpus (53\%) (Table 2). Nonetheless, there are some issues concerning the use of dissection for MP isolation. The first disadvantage is the sample inspection time, which can be as long as 10 min to $1 \mathrm{~h} 30$ [39, 45, 57], leading to a high risk of contamination from the work environment. The second important issue with this methodology is the risk of omitting particles [17, 25]. The first reason for these omissions is that dissections are sometimes performed with the naked eye, which is not accurate enough to distinguish all MP. The second reason is that depending on their size and shape, MP can be difficult to observe among the contents of the alimentary tract.

Concerning chemical digestion of tissues, different methods have been described. These include enzymatic methods (trypsin, proteinase $\mathrm{K}$, mix lipase/amylase/protease), oxidative methods (sodium hypochlorite $(\mathrm{NaClO})$ and hydrogen peroxide $\left(\mathrm{H}_{2} \mathrm{O}_{2}\right)$ ), acid methods (nitric acid $\left(\mathrm{HNO}_{3}\right)$ or a mixture of $\mathrm{HNO}_{3}$ and perchloric acid $\left(\mathrm{HClO}_{4}\right)$ ), and basic methods (potassium hydroxide $(\mathrm{KOH})$ ). The use of $\mathrm{KOH}$ is the most commonly described of the chemical methods used in the studies of the corpus (17\%) (Table 2). This chemical is mostly used at a concentration of $10 \%$, except in one publication where a concentration of $20 \%$ was tested [63]. $\mathrm{KOH}$ was used to digest both bivalves [35, 68, 71] and fish 
tissues $[23,35,44,48,53,60,63,70,75] . \mathrm{KOH}$ has the advantage of having no deleterious effects on several polymer types $[95,96]$. $\mathrm{KOH}$ must, however, be handled with caution, as it is a corrosive compound. In the corpus (Table 2), eight studies (13\%) proposed the use of oxidising solutions such as $9 \% \mathrm{NaClO}$ on fish stomach contents [51], and $30 \% \mathrm{H}_{2} \mathrm{O}_{2}$ on bivalves [30, 33, 42, 59, 69] and fish organs $[31,59,66] . \mathrm{H}_{2} \mathrm{O}_{2}$ is the second most commonly used technique to digest seafood tissues, mostly bivalves. The main concern with oxidising solutions is their stability over time. This must therefore be taken into account in the context of method standardisation. Echoing what was previously discussed (see 3.4) the use of DAC, O/SC and PCE is highly encouraged during the digestion step.

A total of eight studies using acid approaches were found in the corpus (Table 2), among which five $(8 \%)$ used $69 \%$ nitric acid $[29,37,41,47,62]$ and three $(5 \%)$ used a $65 \% \mathrm{HNO}_{3}: 68 \% \mathrm{HClO}_{4} 4: 1(\mathrm{v} / \mathrm{v})$ mixture $[27,32,38]$. The nitric acid method has only been applied to bivalves, while the acid mixture was applied to both bivalves and crustaceans. The main drawback of the acid approach is its adverse effect on polymers, described in numerous studies $[95,97,98]$. Three studies (5\%) used enzymatic digestion for the analysis of bivalve tissues [52, 72] and fish gut [61]. Enzymatic approaches can be considered mild approaches, and they usually do not require temperatures above $40^{\circ} \mathrm{C}$. The second advantage of this type of approach is that enzymes have no impact on synthetic polymers. One of the disadvantages of such methods is the use of a multistep analysis, involving multiple solutions with a higher risk of contamination. As an example, enzymatic digestion was not sufficiently effective on fish gut [61], and an additional step using $30 \% \mathrm{H}_{2} \mathrm{O}_{2}$ was necessary. Moreover, these approaches can sometimes be time consuming. Finally, depending on the method, hazardous reactions can occur, which is not compliant with good hygiene and safety practices. As an example, $\mathrm{H}_{2} \mathrm{O}_{2}$ heating can generate $\mathrm{O}_{2}$, and $\mathrm{NaClO}$ should not be put in acidic conditions because of the release of the highly toxic $\mathrm{Cl}_{2}$ compound.

\subsection{Filtration as the last step in the isolation process}

The last step of in the sampling and isolation process involves filtration when chemical digestion of tissues is performed. The use of FAC is required at this step. Filter retention levels mentioned in the 
corpus (Table 2) (n=31) are $250 \mu \mathrm{m}(3 \%), 200 \mu \mathrm{m}(6 \%), 149 \mu \mathrm{m}(6 \%), 52 \mu \mathrm{m}(3 \%), 20 \mu \mathrm{m}(6 \%), 13$ $\mu \mathrm{m}(10 \%), 12 \mu \mathrm{m}(3 \%), 8 \mu \mathrm{m}(10 \%), 5 \mu \mathrm{m}$ (23\%), $1.6 \mu \mathrm{m}$ (3\%), $1.2 \mu \mathrm{m}(13 \%), 0.8 \mu \mathrm{m}(3 \%)$, and 0.7 $\mu \mathrm{m}(10 \%)$. Regarding these studies, and looking at the filters used, it appears that $61 \%(\mathrm{n}=19)$ chose a retention diameter below $10 \mu \mathrm{m}$. This makes it possible to retain very small MP below the limit of detection of certain identification techniques used downstream (see 5.3). Concerning filter composition, the most common materials are nitrocellulose (29\%) and glass fibre (26\%). For future studies, a compromise between filtration efficacy, i.e. absence of clogging and absence of interference for identification, and MP retention needs to be found and then put forward as a standard.

\subsection{Proposals for standardisation}

405 Based on these findings, some advice can be proposed concerning sampling and isolation, in order to standardise practices. A minimum of 50 individuals must be sampled per studied species (Figure 3), even though statistical analyses are required to assess whether this is representative of population variability. It is important to gather metadata as much as possible, including GPS coordinates for the catch. The second important point to keep in mind is to select individuals that correspond to the commercial size, if risk assessment for human health is considered. Biometric data, i.e. whole size,

411 whole weight and analysed tissue weight are mandatory for study reports in order to improve standardisation of digestion techniques. Once sampled, tissues are to be stored as frozen samples, since the effects of chemical preservatives on polymers are not clearly documented. For particle isolation, the chemical approach should be given preference (Figure 3) as it ensures low exposure of tissues to ambient air and recovery of smaller particles. Two methods are popular in the research community but, to the best of author knowledge, the method using $10 \% \mathrm{KOH}$ at $60^{\circ} \mathrm{C}$ for $24 \mathrm{H}$ is the one whose impact has been assessed most closely; additionally, this solution is more stable over time compared to $30 \%$ $\mathrm{H}_{2} \mathrm{O}_{2}$.

FIGURE 3 goes here (if possible)

420 New methodological parameters concerning digestion should be clarified in future studies to improve method standardisation and comparison of results. The main focus should be to estimate the limits of 
applicability of each method: species, weight of tissues, etc. Various other parameters also need to be better clarified and defined (Figure 3). As an example, the ratio of solution to tissue weight has to be given [27, 32], instead of highly imprecise information such as the volume of solution without reference to tissue weight $[33,41,71]$, or unclear expressions such as "three times the volume of the biological material" $[23,53,64]$. Concerning digestion duration and temperature, certain terms like "overnight" and "room temperature" [27, 32, 37, 38, 47] should also be avoided as they make it difficult for other scientists to reproduce the analysis precisely. Multiple treatments must be thoroughly assessed to avoid unnecessary steps that can lead to contamination, and to determine whether they are necessary for all sample types and sizes. Finally, regarding filtration, harmonisation of filter pores and composition is also needed.

\section{Quantification and identification}

\subsection{Quantification strategies for particle isolation in seafood}

434 The quantification of MP is usually performed by observation under a stereomicroscope. Some studies report observation with the naked eye, but this approach is limited to large MP with sizes above $500 \mu \mathrm{m}$. At this step of the analytical process, "MP-like" or "putative MP" are sorted and generally isolated from the dissected tissue while they are directly counted on the digestate filter $[44,64,66]$. This step is highly tedious, and particularly complicated if the filter is loaded or the contents of the dissected tissue are in 439 large volumes.

440 Currently, automation is theoretically available with both FT-IR and Raman spectroscopy. It has been 441 implemented with both Raman [99] and FT-IR [100] on MP in water and sediment samples. Concerning seafood, automation of particle counting was mentioned in a single publication, without implementation in routine laboratory practice [101], mainly because this approach is still "unreasonably timeconsuming" [102] and because of resolution issues.

Preliminary categorisation of items is generally performed based on particle shapes. As a minimum, 
corpus (Table 2). Six publications explicitly mention that fibres were not included in their evaluation

448 because they were considered laboratory contamination $[17,23,31,37,47,56]$. Nonetheless, it is

449 important to remember that fibres are produced in high quantities [2] and they are not retained by most

450 wastewater treatment plants [103]. With this in mind and with the aim of improving prevention of 451 contamination (see 3.5); it becomes difficult to rule out fibres when studying MP in seafood. Finally, $22 \%$ of studies did not mention fibres; however, most of these studies were carried out before 2013. As a reminder, a list of MP item types was provided by Lusher et al. [104]. It includes fragments, fibres, beads, foams, and pellets.

A second approach consists in sorting items based on their size. To do this, authors generally assess the frequency of items in the different size classes. Considering the studies in the corpus (Table 2) this strategy was performed in $27 \%$ of cases. Once again, the main issue with these studies is that none of them used the same classes, which makes it difficult to compare results.

A third method of sorting is based on particle colour. This approach was adopted in $67 \%$ of the articles of the corpus (Table 2). This sorting approach is also of interest because it enables an orientation test before identification of the items (see 5.2). Of course, particles with colours such as pink, red, blue, or yellow have a higher probability of being synthetic compared to transparent, black or white ones [105].

Until clear identification has been carried out, only the terms MP-like, particle or item should be used.

\subsection{Orientation tests: selection of putative polymers}

465 Once quantification has been performed, there is a need for identification in order to discriminate real 466 MP from non-synthetic particles. Studies that did not perform any identification or orientation represent $46716 \%$ of the corpus (Table 2). Except for one publication [45], all these works were published before 468 2015, showing the attention paid in recent years to better characterisation of isolated particles. Since 2015, the absence of identification seems to have been replaced by orientation tests, but it is important to separate orientation techniques from identification methods. The first indicates the suspected synthetic nature of a particle, while identification leads to clear determination of the polymer composing the MP. 
472 Moreover, it should be mentioned that the sole use of an orientation test is not satisfactory, but it can

473 help to spread non-target particles and avoid overloading analytical devices.

474 Different orientation tests are proposed in $28 \%$ of the corpus articles (Table 2): density tests in solutions

475

476

477

478

479

481

482

483

484

486 with different salinity $[22,44]$, observation of particle characteristics such as colour, shape, and ability to break [25, 30, 35, 36, 41, 43, 44, 50, 61-63], the use of polarised light microscopy [47], the use of a hot needle that leaves a mark on synthetic particles $[27,32,38,39,61]$, and finally colouration with Rose Bengal that stains organic particle leaving mineral, chitin and synthetic material unaffected [17]. Rose Bengal is not the unique colouring agent used for orientation, recently some papers mentioned the use of Nile Red [106] to perform such approach [107].

\subsection{Identification methods to ascertain the nature and quantities of true MP}

Regarding identification, the main technique described in the corpus (Table 2) is Fourier-transform infrared (FT-IR) (48\%), as is or adjusted in different configurations: micro FT-IR, attenuated total reflection (ATR), and focal plan array (FPA) (Table 2). The second described technique is Raman microscopy, used in $9 \%$ of the studies described in the corpus [18, 29, 37, 51, 60, 75].

The main advantages of such techniques are the ability to analyse small particles such as $<20 \mu \mathrm{m}$ and the possibility of coupling particle counting and identification, even though particle isolation is usually performed in seafood. Regarding their drawbacks, FT-IR is generally sensitive to moisture content and not able to identify black particles [108]. Raman technology is not able to easily identify fibres, or particles containing pigments $[29,75]$, and can destroy particles due to the high energy intensity of its laser. Pyrolysis coupled with gas chromatography and mass spectrometry (Py-GC/MS) has not yet been used for seafood studies, contrary to other research fields such as MP in sediment or water. However, a method has been developed and applied on a few MP isolated from bivalves [87]. This technique allows the characterization of the particle core, and recently proved to be efficient in determining polymer composition for samples identified as "pigment" by Raman microscopy [87].

In a context of method comparison and harmonisation of analytical practices, there is a need for method performance assessment. This assessment has been performed for Py-GC/MS [87] with information on 
method development, repeatability, and theoretical limits of detection. Such approaches should also be encouraged for spectroscopic methods allowing for better comparison of results from different studies.

500 As an example of harmonisation, among all FT-IR studies $(\mathrm{n}=21)$, only $52 \%$ provided a threshold 501 beyond which the identification of the polymer's nature is certain, and this threshold varied from $60 \%$ to $85 \%$. None of the six studies performing Raman identification provided such information. Working with the same parameters would help to harmonise identification methods and ultimately enable sharing of research databases, increasing the diversity of spectra available to everyone, and thereby the power of identification of the different tools [102]. Finally, it could be suggested to add positive identification controls (PIC), i.e. a single polymer or multiple known polymers, and negative identification controls (NIC), i.e. a single polymer or multiple natural polymers such as cotton or chitin, to ascertain proper functioning of the analytical device for each batch or particle analysed.

Another issue concerns samples with noise or unidentifiable signals. Among studies having carried out identifications using either Raman or FT-IR spectroscopy $(n=37)$, only $16.2 \%$ reported unidentified items $[34,42,52,60,73,75]$, nonetheless this information is important and should be detailed. Unidentified particles can be either due to absence of spectrum or a noisy signal; chemometric methods are cutting-edge approaches that can help to solve the latter issue. Briefly, chemometry consists in the application of mathematics and statistics, e.g. multivariate analysis for signal processing and correction. A free online analytical pipeline is available to develop chemometric approaches; the Chemflow project (https://vm-chemflow-francegrille.eu/) developed on Galaxy is mostly dedicated to infrared spectrometry. Next steps involve the development of $a d-h o c$ analysis pipelines [100], made available to the research community, able to process problematic spectra and improve identification levels. In parallel to the chemometric approach, as proposed by different authors [102, 109], some works must also be undertaken with weathering and analytical specialists to obtain Raman/FT-IR/Py-GC/MS spectra related to weathered polymers. Indeed, most of the particles found in seafood are secondary sourced MP that have been damaged by the action of UV, oxidisation and swell. This results in spectra that could be 523 different from pristine polymers conventionally used for databases. Moreover, this has been demonstrated for PVC after analysis by $\mu$-Raman [105] and Karami et al. expected that unidentified 
items could partly correspond to weathered polymers [60]. Polymers having known amounts of common additives can also be considered with such approaches to explore whether the plastic additive content could influence identification after weathering processes.

528 Finally, not all particles are usually analysed with the identification tools; a subset of particles is mostly preferred. Regarding the corpus (Table 2), there is huge diversity in the strategies for studies carrying out identifications ( $\mathrm{n}=37)$. Five studies $(14 \%)$ did not report how many particles were analysed or whether there was a selection of items. Seven articles (19\%) reported that they analysed all the particles, while $11(30 \%)$ mentioned a fixed number of particles having been analysed, without information on the proportion of isolated particles that it represents. Fourteen studies (38\%) mentioned analysis of a subset of particles, among which $10(27 \%)$ provided the number of particles analysed vs. the number of isolated particles $[34,42,56,58,59,61,64,66,69,73]$, this practice should be encouraged for future studies. The MSFD provides a strategy concerning identification, proposing that all the particles $<100$ $\mu \mathrm{m}$ should be subject to identification, while for those $>100 \mu \mathrm{m}$, only a subset was proposed; as an example, $10 \%$ could be analysed in the limit of 50 particles [79]. In a recent review, Hermsen et al. proposed another method consisting in studying a minimum of 100 particles when the number of MPlike is less than 200 and more than $50 \%$ of the particles above 200 items [110]. Based on recent studies,

541 it appears that small particles with a size $<100 \mu \mathrm{m}$ represent the majority of particles [71]. The number of items to analyse is thus increasing with the precision of detection devices, and there is a need to 543 define new rules for particle identification. Unfortunately, the above-mentioned proposals are not 544 strongly supported by statistical data. As a result, there is also a need for statistical work to provide 545 advice concerning subsampling, defining the adequate percentage to analyse and to obtain accurate and 546 representative identification of all particles with a high confidence level. Adjustment of the confidence 547 level should be carefully performed, bearing in mind that very high precision will lead to high costs regarding machine and labour times.

549 Identification results are generally given as a list of polymers, followed by the percentage for a given 550 polymer. This allows to easily visualise which polymer is mostly identified, but unfortunately not 
necessarily the one whose quantity is the highest. This fact was illustrated in a recent study on MP in wastewater [86]. As previously discussed (see 2.2), identification data should be combined with quantification data, especially those on size and estimated volumes, in order to estimate the mass of MP present in seafood. This would be of great value for both environmental and human health risk assessment [84].

Once identification has been performed, and provided that identified sub-samples are representative of the whole sampling, and that controls have been thoroughly taken into account, contamination results can be proposed as average MP indiv ${ }^{-1}$ and $\mathrm{MP} \mathrm{g}^{-1}[104]$. The latter result is particularly important when assessing risks to human health and exposure to MP through seafood, using total diet studies.

\subsection{Proposals for standardisation}

561 Concerning quantification and identification, the first parameter to work on concerns automatic particle counting (Figure 4) in order to lower the risk of contamination and increase the number of particles found compared to manual sorting [109]. Common terminologies need to be adopted by the community for the description of particles. Although the different shapes of particles are well defined [104], the other descriptors need to be standardised further. The use of common terminologies will enable easier comparison of studies, and thereby more efficient risk assessment work.

Regarding identification, the comparison of methods on identical samples is suggested and method performance criteria should be established for all the techniques. This will help to evaluate their complementarity (Figure 4), allowing for the establishment of future common identification strategies, or analytical workflows as recently proposed [88], thus saving time and money. Adding identification controls will help to improve quality assurance and participate in standardisation of practices. There is a need to establish, based on statistical criteria of representativeness (Figure 4), accurate rules to define the size of sub-sampling when used for identification. Ultimately, a link between size and identification

574 should be considered in order to approximate MP mass in samples. This will be helpful in environmental and human health risk assessments. 
577

578

579

580

Finally, there are considerable needs concerning approaches in bioinformatics (Figure 4) to enable researchers to identify the currently unidentified spectra. Chemometry and data analysis pipelines would help to remove ambiguities regarding unidentified particles based on statistical tools and enable all scientists to use these difficult methodologies without the need to have extensive knowledge in the field. Finally, the development and pooling of databases, including for weathered polymers, will also improve inter-study reproducibility of identification.

\section{Minimum information for publication of microplastics studies}

As previously highlighted, the number of publications on MP in seafood has increased at an exponential rate in recent years. Unfortunately, some of these publications do not satisfy minimum criteria that should be required to publish a paper dealing with the identification of MP.

Even though a different methodology was used, authors shared some conclusions with the work of Hermsen et al. [110], i.e. the need to work in clean air conditions, the need for contamination controls, or the need for identification to ascertain the polymeric nature of particles. Moreover, authors propose use of recommendation put forward by Lusher et al., concerning, as an example, shape classification and expression of results [104].

\section{TABLE 3 goes here (if possible)}

Authors propose the development of a concept that has already been implemented in other sciences, such as molecular biology [111]: the minimum information for publication of microplastics studies (MIMS). This checklist could be used by people involved in publication from authors to reviewers. The list is proposed in Table 3 and is subdivided following the different items presented in this review that represent the different steps of MP analysis from sampling to identification. A distinction was made between essential information that is mandatory to produce an accurate report on a study, and any desirable information that would add value to the work but whose absence would not affect the overall understanding and the ability to reproduce experiments. This table is the fruit of authors' reflexions and could be used and adapted for other studies dealing with MP contamination in seawater or sediments. 


\section{Conclusion}

603 The study of MP in organisms, including seafood, has essentially developed in the last ten years. That 604 makes it a relatively young field of science. Based on the studies examined in this review, good and less 605 good practices were highlighted. The main information to be drawn from this review is that although in the past much information was missing from the articles, recent studies are more informative concerning

607 for example: contamination prevention, solution filtration, and use of controls. Unfortunately, some 608 practices need to be thoroughly improved such as management of controls, digestion method 609 harmonisation and polymer identification.

610 There is a need to better structure information to improve standardisation, opening the way for the 611 comparison of studies, which is of particular interest for toxicological risk assessment.

612 This review was also an opportunity to reflect on the future challenges facing research on microplastics 613 in seafood. These challenges include developing a more accurate definition of MP in regard to risk 614 assessment, better contamination management thanks to airflow cabinets, the need for harmonisation of 615 digestion methods, and the need to accurately identify isolated MP-like particles. Taking into account 616 the needs of standardisation, as well as the challenges, the concept of MIMS is proposed. This checklist 617 ensures that the minimum information would be proposed to publish an accurate report dealing with experiments concerning microplastics.

619 In the coming years, the above-mentioned challenges should be addressed. This involves 620 interdisciplinary and collaborative work. This will help to improve the quality and accuracy of studies 621 on MP in general, and MP in seafood in particular.

\section{Acknowledgments}

623 Ludovic Hermabessiere would like to thank Région Hauts-de-France and ANSES for the financial 624 support of his PhD. This paper was funded by the French National Research Agency (ANR) (ANR-15625 CE34-0006-02), as part of the Nanoplastics project. 
627 [1] PlasticEurope, Plastics - the Facts 2017: An analysis of European plastics production, demand and data., (2018).

url:

629 https://www.plasticseurope.org/application/files/1715/2111/1527/Plastics_the_facts_2017_FINAL_for_

630 website.pdf (Accessed on 26/08/2018)

631 [2] R. Geyer, J.R. Jambeck, K.L. Law, Production, use, and fate of all plastics ever made, Sci Adv, 3 632 (2017) e1700782. doi: https://doi.org/10.1126/sciadv.1700782

633 [3] A. Ter Halle, L. Jeanneau, M. Martignac, E. Jarde, B. Pedrono, L. Brach, J. Gigault, Nanoplastic in 634 the North Atlantic Subtropical Gyre, Environ Sci Technol, 51 (2017) 13689-13697. doi: 635 https://doi.org/10.1021/acs.est.7b03667

636 [4] R. de Stephanis, J. Gimenez, E. Carpinelli, C. Gutierrez-Exposito, A. Canadas, As main meal for 637 sperm whales: plastics debris, Mar Pollut Bull, 69 (2013) 206-214. doi: 638 https://doi.org/10.1016/j.marpolbul.2013.01.033

639 [5] J.-P.W. Desforges, M. Galbraith, P.S. Ross, Ingestion of Microplastics by Zooplankton in the 640 Northeast Pacific Ocean, Archives of Environmental Contamination and Toxicology, 69 (2015) 320-330. 641 doi: https://doi.org/10.1007/s00244-015-0172-5

642 [6] C. Arthur, J. Baker, H. Bamford, Proceedings of the International Research Workshop on the 643 Occurance, Effects, and Fate of Mircroplastic Marine Debris, Department of Commerce, National 644 Oceanic and Atmospheric Administration, Technical Memorandum NOS-OR\&R-30, DOI (2009).

645 [7] E.R. Zettler, T.J. Mincer, L.A. Amaral-Zettler, Life in the "plastisphere": microbial communities on 646 plastic marine debris, Environ Sci Technol, 47 (2013) 7137-7146. doi: 647 https://doi.org/10.1021/es401288x

648 [8] V. Foulon, F. Le Roux, C. Lambert, A. Huvet, P. Soudant, I. Paul-Pont, Colonization of Polystyrene 649 Microparticles by Vibrio crassostreae: Light and Electron Microscopic Investigation, Environ Sci 650 Technol, 50 (2016) 10988-10996. doi: https://doi.org/10.1021/acs.est.6b02720

651 [9] A.A. Koelmans, A. Bakir, G.A. Burton, C.R. Janssen, Microplastic as a Vector for Chemicals in the 652 Aquatic Environment. Critical Review and Model-Supported Re-interpretation of Empirical Studies, 653 Environmental science \& technology, 50 (2016) 3315-3326. doi: https://doi.org/10.1021/acs.est.5b06069

654 [10] S. Net, R. Sempéré, A. Delmont, A. Paluselli, B. Ouddane, Occurrence, Fate, Behavior and 655 Ecotoxicological State of Phthalates in Different Environmental Matrices, Environmental Science \& 656 Technology, 49 (2015) 4019-4035. doi: https://doi.org/10.1021/es505233b

657 [11] L. Hermabessiere, A. Dehaut, I. Paul-Pont, C. Lacroix, R. Jezequel, P. Soudant, G. Duflos, 658 Occurrence and effects of plastic additives on marine environments and organisms: A review, 659 Chemosphere, 182 (2017) 781-793. doi: https://doi.org/10.1016/j.chemosphere.2017.05.096

660 [12] E.J. Carpenter, S.J. Anderson, G.R. Harvey, H.P. Miklas, B.B. Peck, Polystyrene Spherules in 661 Coastal Waters, Science, 178 (1972) 749-750. doi: https://doi.org/10.1126/science.178.4062.749

662 [13] S. Kartar, F. Abou-Seedo, M. Sainsbury, Polystyrene spherules in the Severn Estuary - A progress 663 report, Marine Pollution Bulletin, 7 (1976). doi: https://doi.org/10.1016/0025-326x(76)90092-8

664 [14] S. Kartar, R.A. Milne, M. Sainsbury, Polystyrene waste in the Severn Estuary, Marine Pollution 665 Bulletin, 4 (1973). doi: https://doi.org/10.1016/0025-326x(73)90010-6

666 [15] C.M. Boerger, G.L. Lattin, S.L. Moore, C.J. Moore, Plastic ingestion by planktivorous fishes in the 667 North Pacific Central Gyre, Mar Pollut Bull, 60 (2010) 2275-2278. doi: 668 https://doi.org/10.1016/j.marpolbul.2010.08.007 
[16] H.E. Braid, J. Deeds, S.L. DeGrasse, J.J. Wilson, J. Osborne, R.H. Hanner, Preying on commercial 670 fisheries and accumulating paralytic shellfish toxins: a dietary analysis of invasive Dosidicus gigas (Cephalopoda Ommastrephidae) stranded in Pacific Canada, Marine Biology, 159 (2011) 25-31. doi: 672 https://doi.org/10.1007/s00227-011-1786-4

673 [17] P. Davison, R.G. Asch, Plastic ingestion by mesopelagic fishes in the North Pacific Subtropical 674 Gyre, Marine Ecology Progress Series, 432 (2011) 173-180. doi: https://doi.org/10.3354/meps09142

[18] F. Murray, P.R. Cowie, Plastic contamination in the decapod crustacean Nephrops norvegicus

(Linnaeus, 1758), Mar Pollut Bull, $62 \quad$ (2011) 1207-1217. doi: https://doi.org/10.1016/j.marpolbul.2011.03.032

678 [19] F.E. Possatto, M. Barletta, M.F. Costa, J.A. do Sul, D.V. Dantas, Plastic debris ingestion by marine 679 catfish: an unexpected fisheries impact, Mar Pollut Bull, 62 (2011) 1098-1102. doi: 680 https://doi.org/10.1016/j.marpolbul.2011.01.036

681 [20] D.V. Dantas, M. Barletta, M.F. da Costa, The seasonal and spatial patterns of ingestion of 682 polyfilament nylon fragments by estuarine drums (Sciaenidae), Environ Sci Pollut Res Int, 19 (2012) 683 600-606. doi: https://doi.org/10.1007/s11356-011-0579-0

684 [21] J.A.A. Ramos, M. Barletta, M.F. Costa, Ingestion of nylon threads by Gerreidae while using a 685 tropical estuary as foraging grounds, Aquatic Biology, 17 (2012) 29-34. doi: 686 https://doi.org/10.3354/ab00461

687 [22] C.A. Choy, J.C. Drazen, Plastic for dinner? Observations of frequent debris ingestion by pelagic 688 predatory fishes from the central North Pacific, Marine Ecology Progress Series, 485 (2013) 155-163. 689 doi: https://doi.org/10.3354/meps10342

690 [23] E.M. Foekema, C. De Gruijter, M.T. Mergia, J.A. van Franeker, A.J. Murk, A.A. Koelmans, Plastic 691 in north sea fish, Environ Sci Technol, 47 (2013) 8818-8824. doi: https://doi.org/10.1021/es400931b

692 [24] M. Gassel, S. Harwani, J.S. Park, A. Jahn, Detection of nonylphenol and persistent organic 693 pollutants in fish from the North Pacific Central Gyre, Mar Pollut Bull, 73 (2013) 231-242. doi: 694 https://doi.org/10.1016/j.marpolbul.2013.05.014

695 [25] L.A. Jantz, C.L. Morishige, G.L. Bruland, C.A. Lepczyk, Ingestion of plastic marine debris by 696 longnose lancetfish (Alepisaurus ferox) in the North Pacific Ocean, Mar Pollut Bull, 69 (2013) 97-104. 697 doi: https://doi.org/10.1016/j.marpolbul.2013.01.019

698 [26] A. Lusher, M. McHugh, R. Thompson, Occurrence of microplastics in the gastrointestinal tract of 699 pelagic and demersal fish from the English Channel, Marine Pollution Bulletin, 67 (2013) 94-99. doi: 700 https://doi.org/10.1016/j.marpolbul.2012.11.028

701 [27] B. De Witte, L. Devriese, K. Bekaert, S. Hoffman, G. Vandermeersch, K. Cooreman, J. Robbens, 702 Quality assessment of the blue mussel (Mytilus edulis): comparison between commercial and wild types, 703 Mar Pollut Bull, 85 (2014) 146-155. doi: https://doi.org/10.1016/j.marpolbul.2014.06.006

704 [28] V. Kripa, P.G. Nair, A. Dhanya, V. Pravitha, K. Abhilash, A.A. Mohammed, D. Vijayan, P. Vishnu, 705 G. Mohan, P. Anilkumar, Microplastics in the gut of anchovies caught from the mud bank area of 706 Alappuzha, Kerala, Marine Fisheries Information Service; Technical and Extension Series, DOI (2014) $707 \quad 27-28$.

708 [29] L. Van Cauwenberghe, C.R. Janssen, Microplastics in bivalves cultured for human consumption, 709 Environ Pollut, 193 (2014) 65-70. doi: https://doi.org/10.1016/j.envpol.2014.06.010

710 [30] A. Mathalon, P. Hill, Microplastic fibers in the intertidal ecosystem surrounding Halifax Harbor, 711 Nova Scotia, Mar Pollut Bull, 81 (2014) 69-79. doi: https://doi.org/10.1016/j.marpolbul.2014.02.018

712 [31] C.G. Avio, S. Gorbi, F. Regoli, Experimental development of a new protocol for extraction and 713 characterization of microplastics in fish tissues: First observations in commercial species from Adriatic 714 Sea, Mar Environ Res, 111 (2015) 18-26. doi: https://doi.org/10.1016/j.marenvres.2015.06.014 

Vethaak, Microplastic contamination in brown shrimp (Crangon crangon, Linnaeus 1758) from coastal waters of the Southern North Sea and Channel area, Mar Pollut Bull, 98 (2015) 179-187. doi: https://doi.org/10.1016/j.marpolbul.2015.06.051

[33] J. Li, D. Yang, L. Li, K. Jabeen, H. Shi, Microplastics in commercial bivalves from China, Environ Pollut, 207 (2015) 190-195. doi: https://doi.org/10.1016/j.envpol.2015.09.018

[34] D. Neves, P. Sobral, J.L. Ferreira, T. Pereira, Ingestion of microplastics by commercial fish off the Portuguese coast, Mar Pollut Bull, $101 \quad$ (2015) 119-126. doi: https://doi.org/10.1016/j.marpolbul.2015.11.008

[35] C.M. Rochman, A. Tahir, S.L. Williams, D.V. Baxa, R. Lam, J.T. Miller, F.C. Teh, S. Werorilangi, S.J. Teh, Anthropogenic debris in seafood: Plastic debris and fibers from textiles in fish and bivalves sold for human consumption, Sci Rep, 5 (2015) 14340. doi: https://doi.org/10.1038/srep14340

[36] T. Romeo, B. Pietro, C. Peda, P. Consoli, F. Andaloro, M.C. Fossi, First evidence of presence of plastic debris in stomach of large pelagic fish in the Mediterranean Sea, Mar Pollut Bull, 95 (2015) 358361. doi: https://doi.org/10.1016/j.marpolbul.2015.04.048

[37] L. Van Cauwenberghe, M. Claessens, M.B. Vandegehuchte, C.R. Janssen, Microplastics are taken up by mussels (Mytilus edulis) and lugworms (Arenicola marina) living in natural habitats, Environ Pollut, 199 (2015) 10-17. doi: https://doi.org/10.1016/j.envpol.2015.01.008 [38] G. Vandermeersch, L. Van Cauwenberghe, C.R. Janssen, A. Marques, K. Granby, G. Fait, M.J. Kotterman, J. Diogene, K. Bekaert, J. Robbens, L. Devriese, A critical view on microplastic quantification in aquatic organisms, Environ Res, 143 (2015) 46-55. doi: https://doi.org/10.1016/j.envres.2015.07.016

[39] J. Bellas, J. Martinez-Armental, A. Martinez-Camara, V. Besada, C. Martinez-Gomez, Ingestion of microplastics by demersal fish from the Spanish Atlantic and Mediterranean coasts, Mar Pollut Bull, 109 (2016) 55-60. doi: https://doi.org/10.1016/j.marpolbul.2016.06.026

[40] I.L.N. Bråte, D.P. Eidsvoll, C.C. Steindal, K.V. Thomas, Plastic ingestion by Atlantic cod (Gadus morhua) from the Norwegian coast, Mar Pollut Bull, 112 (2016) 105-110. doi: https://doi.org/10.1016/j.marpolbul.2016.08.034

[41] K. Davidson, S.E. Dudas, Microplastic Ingestion by Wild and Cultured Manila Clams (Venerupis philippinarum) from Baynes Sound, British Columbia, Arch Environ Contam Toxicol, 71 (2016) 147156. doi: https://doi.org/10.1007/s00244-016-0286-4

[42] J. Li, X. Qu, L. Su, W. Zhang, D. Yang, P. Kolandhasamy, D. Li, H. Shi, Microplastics in mussels along the coastal waters of China, Environ Pollut, 214 (2016) 177-184. doi: https://doi.org/10.1016/j.envpol.2016.04.012

[43] M. Liboiron, F. Liboiron, E. Wells, N. Richard, A. Zahara, C. Mather, H. Bradshaw, J. Murichi, Low plastic ingestion rate in Atlantic cod (Gadus morhua) from Newfoundland destined for human consumption collected through citizen science methods, Mar Pollut Bull, 113 (2016) 428-437. doi: https://doi.org/10.1016/j.marpolbul.2016.10.043

[44] A.L. Lusher, C. O'Donnell, R. Officer, I. O'Connor, Microplastic interactions with North Atlantic mesopelagic fish, ICES Journal of Marine Science: Journal du Conseil, 73 (2016) 1214-1225. doi: https://doi.org/10.1093/icesjms/fsv241

[45] M.A. Nadal, C. Alomar, S. Deudero, High levels of microplastic ingestion by the semipelagic fish bogue Boops boops (L.) around the Balearic Islands, Environ Pollut, 214 (2016) 517-523. doi: https://doi.org/10.1016/j.envpol.2016.04.054

[46] C.D. Rummel, M.G. Loder, N.F. Fricke, T. Lang, E.M. Griebeler, M. Janke, G. Gerdts, Plastic ingestion by pelagic and demersal fish from the North Sea and Baltic Sea, Mar Pollut Bull, 102 (2016) 134-141. doi: https://doi.org/10.1016/j.marpolbul.2015.11.043 
[47] M.F. Santana, L.G. Ascer, M.R. Custodio, F.T. Moreira, A. Turra, Microplastic contamination in natural mussel beds from a Brazilian urbanized coastal region: Rapid evaluation through bioassessment, Mar Pollut Bull, 106 (2016) 183-189. doi: https://doi.org/10.1016/j.marpolbul.2016.02.074

[48] K. Tanaka, H. Takada, Microplastic fragments and microbeads in digestive tracts of planktivorous fish from urban coastal waters, Sci Rep, 6 (2016) 34351. doi: https://doi.org/10.1038/srep34351

[49] N.A.C. Welden, P.R. Cowie, Environment and gut morphology influence microplastic retention in langoustine, Nephrops norvegicus, Environ Pollut, 214 (2016) 859-865. doi: https://doi.org/10.1016/j.envpol.2016.03.067

[50] D. Wójcik-Fudalewska, M. Normant-Saremba, P. Anastacio, Occurrence of plastic debris in the stomach of the invasive crab Eriocheir sinensis, Mar Pollut Bull, 113 (2016) 306-311. doi: https://doi.org/10.1016/j.marpolbul.2016.09.059

[51] F. Collard, B. Gilbert, G. Eppe, L. Roos, P. Compere, K. Das, E. Parmentier, Morphology of the filtration apparatus of three planktivorous fishes and relation with ingested anthropogenic particles, Mar Pollut Bull, 116 (2017) 182-191. doi: https://doi.org/10.1016/j.marpolbul.2016.12.067

[52] W. Courtene-Jones, B. Quinn, F. Murphy, S.F. Gary, B.E. Narayanaswamy, Optimisation of enzymatic digestion and validation of specimen preservation methods for the analysis of ingested microplastics, Analytical Methods, 9 (2017) 1437-1445. doi: https://doi.org/10.1039/c6ay02343f

[53] E. Hermsen, R. Pompe, E. Besseling, A.A. Koelmans, Detection of low numbers of microplastics in North Sea fish using strict quality assurance criteria, Marine pollution bulletin, 122 (2017) 253-258. doi: https://doi.org/10.1016/j.marpolbul.2017.06.051

[54] A.R. McGoran, P.F. Clark, D. Morritt, Presence of microplastic in the digestive tracts of European flounder, Platichthys flesus, and European smelt, Osmerus eperlanus, from the River Thames, Environ Pollut, 220 (2017) 744-751. doi: https://doi.org/10.1016/j.envpol.2016.09.078

[55] F. Murphy, M. Russell, C. Ewins, B. Quinn, The uptake of macroplastic \& microplastic by demersal $\&$ pelagic fish in the Northeast Atlantic around Scotland, Mar Pollut Bull, 122 (2017) 353-359. doi: https://doi.org/10.1016/j.marpolbul.2017.06.073

[56] N.C. Ory, P. Sobral, J.L. Ferreira, M. Thiel, Amberstripe scad Decapterus muroadsi (Carangidae) fish ingest blue microplastics resembling their copepod prey along the coast of Rapa Nui (Easter Island) in the South Pacific subtropical gyre, Sci Total Environ, 586 (2017) 430-437. doi: https://doi.org/10.1016/j.scitotenv.2017.01.175

[57] C. Alomar, A. Sureda, X. Capo, B. Guijarro, S. Tejada, S. Deudero, Microplastic ingestion by Mullus surmuletus Linnaeus, 1758 fish and its potential for causing oxidative stress, Environ Res, 159 (2017) 135-142. doi: https://doi.org/10.1016/j.envres.2017.07.043

[58] O. Güven, K. Gokdag, B. Jovanovic, A.E. Kideys, Microplastic litter composition of the Turkish territorial waters of the Mediterranean Sea, and its occurrence in the gastrointestinal tract of fish, Environ Pollut, 223 (2017) 286-294. doi: https://doi.org/10.1016/j.envpol.2017.01.025

[59] K. Jabeen, L. Su, J. Li, D. Yang, C. Tong, J. Mu, H. Shi, Microplastics and mesoplastics in fish from coastal and fresh waters of China, Environ Pollut, 221 (2017) 141-149. doi: https://doi.org/10.1016/j.envpol.2016.11.055

[60] A. Karami, A. Golieskardi, Y.B. Ho, V. Larat, B. Salamatinia, Microplastics in eviscerated flesh and excised organs of dried fish, Sci Rep, 7 (2017) 5473. doi: https://doi.org/10.1038/s41598-017-05828-6

[61] T.M. Karlsson, A.D. Vethaak, B.C. Almroth, F. Ariese, M. van Velzen, M. Hassellov, H.A. Leslie, Screening for microplastics in sediment, water, marine invertebrates and fish: Method development and microplastic accumulation, Mar Pollut Bull, 122 (2017) 403-408. doi: https://doi.org/10.1016/j.marpolbul.2017.06.081 
[62] H.A. Leslie, S.H. Brandsma, M.J. van Velzen, A.D. Vethaak, Microplastics en route: Field measurements in the Dutch river delta and Amsterdam canals, wastewater treatment plants, North Sea sediments and biota, Environ Int, 101 (2017) 133-142. doi: https://doi.org/10.1016/j.envint.2017.01.018

[63] R. Mizraji, C. Ahrendt, D. Perez-Venegas, J. Vargas, J. Pulgar, M. Aldana, F. Patricio Ojeda, C. Duarte, C. Galban-Malagon, Is the feeding type related with the content of microplastics in intertidal fish gut?, Mar Pollut Bull, 116 (2017) 498-500. doi: https://doi.org/10.1016/j.marpolbul.2017.01.008

813 [64] F. Bessa, P. Barria, J.M. Neto, J. Frias, V. Otero, P. Sobral, J.C. Marques, Occurrence of 814 microplastics in commercial fish from a natural estuarine environment, Mar Pollut Bull, 128 (2018) 575584. doi: https://doi.org/10.1016/j.marpolbul.2018.01.044

[65] E. Carreras-Colom, M. Constenla, A. Soler-Membrives, J.E. Cartes, M. Baeza, F. Padros, M. Carrasson, Spatial occurrence and effects of microplastic ingestion on the deep-water shrimp Aristeus antennatus, Mar Pollut Bull, 133 (2018) 44-52. doi: https://doi.org/10.1016/j.marpolbul.2018.05.012

[66] N. Digka, C. Tsangaris, M. Torre, A. Anastasopoulou, C. Zeri, Microplastics in mussels and fish 820 from the Northern Ionian Sea, Marine Pollution Bulletin, 135 (2018) 30-40. doi: https://doi.org/10.1016/j.marpolbul.2018.06.063

[67] S. Kühn, F.L. Schaafsma, B. van Werven, H. Flores, M. Bergmann, M. Egelkraut-Holtus, M.B. Tekman, J.A. van Franeker, Plastic ingestion by juvenile polar cod (Boreogadus saida) in the Arctic Ocean, Polar Biology, 41 (2018) 1269-1278. doi: https://doi.org/10.1007/s00300-018-2283-8 (2018) 619-625. doi: https://doi.org/10.1016/j.envpol.2018.01.083

[69] J. Li, C. Green, A. Reynolds, H. Shi, J.M. Rotchell, Microplastics in mussels sampled from coastal waters and supermarkets in the United Kingdom, Environ Pollut, 241 (2018) 35-44. doi: https://doi.org/10.1016/j.envpol.2018.05.038

831 [70] G. Pellini, A. Gomiero, T. Fortibuoni, C. Ferra, F. Grati, A.N. Tassetti, P. Polidori, G. Fabi, G. 832 Scarcella, Characterization of microplastic litter in the gastrointestinal tract of Solea solea from the Adriatic Sea, Environ Pollut, 234 (2018) 943-952. doi: https://doi.org/10.1016/j.envpol.2017.12.038 microplastic contamination of bivalves from the French Atlantic coast: Location, season and/or mode of life?, Mar Pollut Bull, 129 (2018) 664-674. doi: https://doi.org/10.1016/j.marpolbul.2017.10.054

[72] S. Railo, J. Talvitie, O. Setala, A. Koistinen, M. Lehtiniemi, Application of an enzyme digestion method reveals microlitter in Mytilus trossulus at a wastewater discharge area, Mar Pollut Bull, 130 (2018) 206-214. doi: https://doi.org/10.1016/j.marpolbul.2018.03.022

840 [73] N.A. Welden, B. Abylkhani, L.M. Howarth, The effects of trophic transfer and environmental factors on microplastic uptake by plaice, Pleuronectes plastessa, and spider crab, Maja squinado, Environ Pollut, 239 (2018) 351-358. doi: https://doi.org/10.1016/j.envpol.2018.03.110

843 [74] M. Compa, A. Ventero, M. Iglesias, S. Deudero, Ingestion of microplastics and natural fibres in 844 Sardina pilchardus (Walbaum, 1792) and Engraulis encrasicolus (Linnaeus, 1758) along the Spanish 845 Mediterranean coast, Mar Pollut Bull, $128 \quad$ (2018) 89-96. doi: 846 https://doi.org/10.1016/j.marpolbul.2018.01.009

847 [75] A. Karami, A. Golieskardi, C.K. Choo, V. Larat, S. Karbalaei, B. Salamatinia, Microplastic and 848 mesoplastic contamination in canned sardines and sprats, Sci Total Environ, 612 (2018) 1380-1386. doi: 849 https://doi.org/10.1016/j.scitotenv.2017.09.005

850 [76] GESAMP, Sources, fate and effects of microplastics in the marine environment :part two of global 851 assessment, 2015. 

and Aquaculture Technical Paper, FAO, 2017.

[78] OSPAR, OSPAR request on development of a common monitoring protocol for plastic particles in fish stomachs and selected shellfish on the basis of existing fish disease surveys, ICES Advice 2015 Book 1, 2015, pp. 1-6.

[79] F. Galgani, G. Hanke, S. Werner, L. Oosterbaan, P. Nilsson, D. Fleet, S. Kinsey, R.C. Thompson, J. van Franeker, T. Vlachogianni, M. Scoullos, J.M. Veiga, A. Palatinus, M. Matiddi, T. Maes, S. Korpinen, A. Budziak, H. Leslie, J. Gago, G. Liebezeit, Guidance on Monitoring of Marine Litter in European Seas, JRC Scientific and Policy Reports, European Commission, Luxembourg, 2013. Accumulation of microplastic on shorelines woldwide: sources and sinks, Environ Sci Technol, 45 (2011) 9175-9179. doi: https://doi.org/10.1021/es201811s

864

[81] J. Gigault, A.T. Halle, M. Baudrimont, P.Y. Pascal, F. Gauffre, T.L. Phi, H. El Hadri, B. Grassl, S. Reynaud, Current opinion: What is a nanoplastic?, Environ Pollut, 235 (2018) 1030-1034. doi: https://doi.org/10.1016/j.envpol.2018.01.024

[82] A.A. Koelmans, E. Besseling, W.J. Shim, Nanoplastics in the Aquatic Environment. Critical Review, in: M. Bergmann, L. Gutow, M. Klages (Eds.) Marine Anthropogenic Litter, Springer International Publishing, Cham, 2015, pp. 325-340. doi: https://doi.org/10.1007/978-3-319-16510-3_12

[83] M. Filella, Questions of size and numbers in environmental research on microplastics: methodological and conceptual aspects, Environmental Chemistry, 12 (2015) 527-538. doi: https://doi.org/10.1071/EN15012

[84] M. Smith, D.C. Love, C.M. Rochman, R.A. Neff, Microplastics in Seafood and the Implications for Human Health, Curr Environ Health Rep, DOI https://doi.org/10.1007/s40572-018-0206-z(2018). doi: https://doi.org/10.1007/s40572-018-0206-z

[85] A.D. Gray, J.E. Weinstein, Size- and shape-dependent effects of microplastic particles on adult daggerblade grass shrimp (Palaemonetes pugio), Environ Toxicol Chem, 36 (2017) 3074-3080. doi: https://doi.org/10.1002/etc.3881

[86] M. Simon, N. van Alst, J. Vollertsen, Quantification of microplastic mass and removal rates at wastewater treatment plants applying Focal Plane Array (FPA)-based Fourier Transform Infrared (FTIR) imaging, Water Research, 142 (2018) 1-9. doi: https://doi.org/10.1016/j.watres.2018.05.019

[87] L. Hermabessiere, C. Himber, B. Boricaud, M. Kazour, R. Amara, A.-L. Cassone, M. Laurentie, I. Paul-Pont, P. Soudant, A. Dehaut, G. Duflos, Optimization, performance and application of a PyrolysisGC/MS method for the identification of microplastics, Analytical and Bioanalytical Chemistry, 410 (2018) 6663-6676. doi: https://doi.org/10.1007/s00216-018-1279-0

[88] S.M. Mintenig, P.S. Bäuerlein, A.A. Koelmans, S.C. Dekker, A.P. van Wezel, Closing the gap between small and smaller: towards a framework to analyse nano- and microplastics in aqueous environmental samples, Environmental Science: Nano, 5 (2018) 1640-1649. doi: https://doi.org/10.1039/C8EN00186C

890 [89] I. Paul-Pont, K. Tallec, C. Gonzalez-Fernandez, C. Lambert, D. Vincent, D. Mazurais, J.-L. 891 Zambonino-Infante, G. Brotons, F. Lagarde, C. Fabioux, P. Soudant, A. Huvet, Constraints and Priorities for Conducting Experimental Exposures of Marine Organisms to Microplastics, Frontiers in Marine Science, 5 (2018). doi: https://doi.org/10.3389/fmars.2018.00252

[90] C. Wesch, A.M. Elert, M. Worner, U. Braun, R. Klein, M. Paulus, Assuring quality in microplastic monitoring: About the value of clean-air devices as essentials for verified data, Sci Rep, 7 (2017) 5424. doi: https://doi.org/10.1038/s41598-017-05838-4 
[91] Council Regulation, Council Regulation (EC) No 850/98 of 30 March 1998 for the conservation of 898 fishery resources through technical measures for the protection of juveniles of marine organisms, in: 899 European Union (Ed.), Official Journal of the European Union, 1998, pp. 72-74.

900 [92] Y. Verin, IBTS 2017 cruise, RV Thalassa, DOI https://doi.org/10.17600/17001700(2017). doi: 901 https://doi.org/10.17600/17001700

902 [93] M. Travers-Trolet, CGFS2017 cruise, RV Thalassa, DOI https://doi.org/10.17600/17002200(2017). 903 doi: https://doi.org/10.17600/17002200

904 [94] M.G. Burgaard, Effect of frozen storage temperature on quality-related changes in fish muscle, 905 Food, DTU, 2010.

906 [95] A. Dehaut, A.-L. Cassone, L. Frère, L. Hermabessiere, C. Himber, E. Rinnert, G. Rivière, C. 907 Lambert, P. Soudant, A. Huvet, G. Duflos, I. Paul-Pont, Microplastics in seafood: Benchmark protocol 908 for their extraction and characterization, Environmental Pollution, 215 (2016) 223-233. doi: 909 https://doi.org/10.1016/j.envpol.2016.05.018

910 [96] S. Kühn, B. van Werven, A. van Oyen, A. Meijboom, E.L. Bravo Rebolledo, J.A. van Franeker, The 911 use of potassium hydroxide $(\mathrm{KOH})$ solution as a suitable approach to isolate plastics ingested by marine 912 organisms, Marine Pollution Bulletin, $115 \quad$ (2017) 86-90. doi: 913 https://doi.org/10.1016/j.marpolbul.2016.11.034

914 [97] M. Claessens, L. Van Cauwenberghe, M.B. Vandegehuchte, C.R. Janssen, New techniques for the 915 detection of microplastics in sediments and field collected organisms, Marine Pollution Bulletin, 70 916 (2013) 227-233. doi: https://doi.org/10.1016/j.marpolbul.2013.03.009

917 [98] A. Karami, A. Golieskardi, C.K. Choo, N. Romano, Y.B. Ho, B. Salamatinia, A high-performance 918 protocol for extraction of microplastics in fish, Science of The Total Environment, 578 (2017) 485-494. 919 doi: https://doi.org/10.1016/j.scitotenv.2016.10.213

920 [99] L. Frère, I. Paul-Pont, J. Moreau, P. Soudant, C. Lambert, A. Huvet, E. Rinnert, A semi-automated 921 Raman micro-spectroscopy method for morphological and chemical characterizations of microplastic 922 litter, Marine Pollution Bulletin, 113 (2016) 461-468. doi: 923 https://doi.org/10.1016/j.marpolbul.2016.10.051

924 [100] S. Primpke, C. Lorenz, R. Rascher-Friesenhausen, G. Gerdts, An automated approach for 925 microplastics analysis using focal plane array (FPA) FTIR microscopy and image analysis, Anal. 926 Methods, 9 (2017) 1499-1511. doi: https://doi.org/10.1039/c6ay02476a

927 [101] N.N. Phuong, A. Zalouk-Vergnoux, A. Kamari, C. Mouneyrac, F. Amiard, L. Poirier, F. Lagarde, 928 Quantification and characterization of microplastics in blue mussels (Mytilus edulis): protocol setup and 929 preliminary data on the contamination of the French Atlantic coast, Environmental Science and 930 Pollution Research, 25 (2018) 6135-6144. doi: https://doi.org/10.1007/s11356-017-8862-3

931 [102] P. Ribeiro-Claro, M.M. Nolasco, C. Araújo, Chapter 5 - Characterization of Microplastics by 932 Raman Spectroscopy, in: T.A.P. Rocha-Santos, A.C. Duarte (Eds.) Comprehensive Analytical Chemistry, 933 Elsevier2017, pp. 119-151. doi: https://doi.org/10.1016/bs.coac.2016.10.001

934 [103] F. Salvador Cesa, A. Turra, J. Baruque-Ramos, Synthetic fibers as microplastics in the marine 935 environment: A review from textile perspective with a focus on domestic washings, Science of The Total 936 Environment, 598 (2017) 1116-1129. doi: https://doi.org/10.1016/j.scitotenv.2017.04.172

937 [104] A.L. Lusher, N.A. Welden, P. Sobral, M. Cole, Sampling, isolating and identifying microplastics 938 ingested by fish and invertebrates, Analytical Methods, 9 (2017) 1346-1360. doi: 939 https://doi.org/10.1039/C6AY02415G

940 [105] R. Lenz, K. Enders, C.A. Stedmon, D.M. Mackenzie, T.G. Nielsen, A critical assessment of visual 941 identification of marine microplastic using Raman spectroscopy for analysis improvement, Mar Pollut 942 Bull, 100 (2015) 82-91. doi: https://doi.org/10.1016/j.marpolbul.2015.09.026 
943 [106] W.J. Shim, Y.K. Song, S.H. Hong, M. Jang, Identification and quantification of microplastics 944 using Nile Red staining, Marine Pollution Bulletin, 113 (2016) 469-476. doi: 945 https://doi.org/10.1016/j.marpolbul.2016.10.049

946 [107] A.I. Catarino, V. Macchia, W.G. Sanderson, R.C. Thompson, T.B. Henry, Low levels of microplastics (MP) in wild mussels indicate that MP ingestion by humans is minimal compared to exposure via household fibres fallout during a meal, Environ Pollut, 237 (2018) 675-684. doi: https://doi.org/10.1016/j.envpol.2018.02.069

950 [108] A. Kappler, D. Fischer, S. Oberbeckmann, G. Schernewski, M. Labrenz, K.J. Eichhorn, B. Voit, 951 Analysis of environmental microplastics by vibrational microspectroscopy: FTIR, Raman or both?, Anal 952 Bioanal Chem, 408 (2016) 8377-8391. doi: https://doi.org/10.1007/s00216-016-9956-3

953 [109] A.B. Silva, A.S. Bastos, C.I.L. Justino, J.P. da Costa, A.C. Duarte, T.A.P. Rocha-Santos, 954 Microplastics in the environment: Challenges in analytical chemistry - A review, Analytica Chimica 955 Acta, 1017 (2018) 1-19. doi: https://doi.org/10.1016/j.aca.2018.02.043

956 [110] E. Hermsen, S.M. Mintenig, E. Besseling, A.A. Koelmans, Quality Criteria for the Analysis of 957 Microplastic in Biota Samples: A Critical Review, Environ Sci Technol, DOI 958 https://doi.org/10.1021/acs.est.8b01611(2018). doi: https://doi.org/10.1021/acs.est.8b01611

959 [111] S.A. Bustin, V. Benes, J.A. Garson, J. Hellemans, J. Huggett, M. Kubista, R. Mueller, T. Nolan, 960 M.W. Pfaffl, G.L. Shipley, J. Vandesompele, C.T. Wittwer, The MIQE guidelines: Minimum information 961 for publication of quantitative real-time PCR experiments, Clinical Chemistry, 55 (2009) 611-622. doi: 962 https://doi.org/10.1373/clinchem.2008.112797

\section{Captions}

965 Figure 1: Pictures of microparticles and potential MP isolated from a laboratory ventilation grid (A) and the surface of 966 an operator's finger (B) where fibres are pointed out by arrows.

967 Figure 2: Representation of basic precautions to avoid sample contamination in the context of MP load analysis.

968 Figure 3: Schematic representation of proposal for standardization of sampling and isolation. SAC: sampling 969 atmospheric control, PEC: positive extraction control, O/SC: operator/solution control, DAC: digestion atmospheric 970 control, FAC: filtration atmospheric control.

971 Figure 4: Schematic representation of proposal for standardization of quantification and identification. PE: polyethylene, PP: polypropylene, PS: polystyrene, $\mu$ Raman: Raman microspectroscopy, $\mu$ FT-IR: Fourier-transform infrared microspectroscopy, Py-GC/MS: pyrolysis coupled to gas chromatography and mass spectrometry.

Table 1: Comparison of cube, sphere and fibre lengths, diameters, volumes and areas considering equal maximum size and volumes.

976 Table 2: Reading grid showing the main points selected from the studies in the corpus.

Table 3: Minimum information for publication of microplastics studies (MIMS). 


\section{SAMPLING}

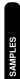

sa ind viduels minmum

Tosua dasectien

号

号

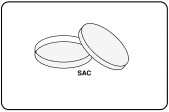

\section{DIGESTION}

\section{$\%$ Aatio}
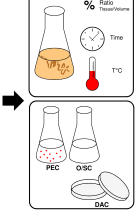

\section{FILTRATION}

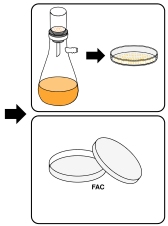



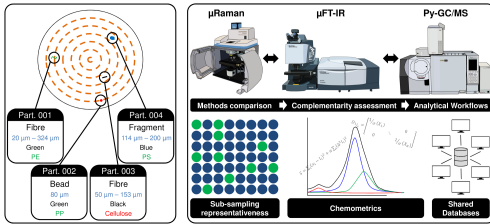

Methods comparison Complementarity assessment Analytical Worktlows

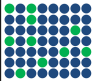

Sub-8ampling representatheness
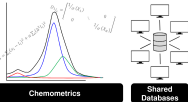

Shared Databeses 
Table 1

Cube Sphere Fibre $^{\text {a }}$

Equal maximum size

$\begin{array}{lccc}\text { Lengths (L) } & 5 \mathrm{~mm} & - & 5 \mathrm{~mm} \\ \text { Diameters (D) }_{\text {Areas b }}^{\text {b }} & - & 5 \mathrm{~mm} & 0,05 \mathrm{~mm} \\ \text { Volumes }^{\text {c }} & 150 \mathrm{~mm}^{2} & 79 \mathrm{~mm}^{2} & 0,79 \mathrm{~mm}^{2} \\ \text { Volum }^{3} & 125 \mathrm{~mm}^{3} & 65 \mathrm{~mm}^{3} & 0,01 \mathrm{~mm}^{3}\end{array}$

Equal volumes

\begin{tabular}{lccc} 
Lengths (L) & $3,7 \mathrm{~mm}$ & - & $25465 \mathrm{~mm}$ \\
Diameters (D) & - & $4,6 \mathrm{~mm}$ & $0,05 \mathrm{~mm}$ \\
Areas b & $81 \mathrm{~mm}^{2}$ & $66 \mathrm{~mm}^{2}$ & $4000 \mathrm{~mm}^{2}$ \\
Volumes c & $50 \mathrm{~mm}^{3}$ & $50 \mathrm{~mm}^{3}$ & $50 \mathrm{~mm}^{3}$ \\
\hline
\end{tabular}

${ }^{a}$ Fibre is here considered as a cylinder

${ }^{\mathrm{b}}$ Areas were calculated using different formulas: $6 \times L^{2}$ for the cube, $4 \pi \times\left(\frac{D}{2}\right)^{2}$ for the sphere and $2 \pi \times\left(\frac{D}{2}\right)^{2}+2 \pi \times\left(\frac{D}{2}\right) \times L$ for the fibre.

${ }^{c}$ Volumes were calculated using different formulas: $L^{3}$ for cube, $\frac{4}{3} \pi \times\left(\frac{D}{2}\right)^{3}$ for the sphere and $L \times \pi \times\left(\frac{D}{2}\right)^{2}$ for the fibre. 
Table 2

\begin{tabular}{|c|c|c|c|c|c|c|c|c|c|c|c|c|c|c|c|c|c|c|c|c|c|c|c|}
\hline \multirow[b]{2}{*}{ Ref. } & \multirow[b]{2}{*}{ Year } & \multicolumn{7}{|c|}{ Contamination prevention } & \multicolumn{5}{|c|}{ Sampling } & \multicolumn{6}{|c|}{ Isolation } & \multicolumn{3}{|c|}{ Quantification } & \multirow{2}{*}{$\begin{array}{c}\text { Identification } \\
\text { Methods }^{\mathrm{m}}\end{array}$} \\
\hline & & $\begin{array}{c}\text { Cotton lab } \\
\text { coat }^{\mathrm{a}}\end{array}$ & $\begin{array}{c}\text { Cleaning } \\
\text { procedure }^{\mathrm{b}}\end{array}$ & $\begin{array}{l}\text { Sol. } \\
\text { filtration }\end{array}$ & $\begin{array}{l}\text { Working } \\
\text { place }^{\text {c }}\end{array}$ & Blanks $^{\mathrm{d}}$ & $\begin{array}{c}\text { Blanks } \\
\text { management }\end{array}$ & Blank results ${ }^{\mathrm{e}}$ & $\begin{array}{l}\text { Aver. } \\
\text { Length }{ }^{\mathrm{f}}\end{array}$ & Aver. weight ${ }^{\mathrm{f}}$ & $\mathrm{n}^{\mathrm{f}}$ & $\begin{array}{c}\text { Organism } \\
\mathrm{s}^{\mathrm{g}}\end{array}$ & Method & Concentration & Ratio $^{\mathrm{h}}$ & Time $^{i}$ & $\mathrm{~T}^{\circ} \mathrm{C}^{\mathrm{j}}$ & $\begin{array}{c}\text { Comp. } \\
\text { Treat } \\
\end{array}$ & Filters $^{k}$ & Sizes $^{1}$ & Colors & Fibers & \\
\hline$\overline{[12]}$ & 1972 & - & - & - & - & - & - & - & - & - & 270 & $\mathrm{~F}$ & Dissection & - & - & - & - & - & - & $\begin{array}{l}\text { Yes } \\
\text { Yon }\end{array}$ & Yes & - & $\begin{array}{l}\text { FT-IR } \\
\end{array}$ \\
\hline [13] & 1973 & - & - & - & - & - & - & - & Part. & - & - & $\mathrm{F}$ & Dissection & - & - & - & - & - & - & - & Yes & - & - \\
\hline [14] & 1976 & - & - & - & - & - & - & - & - & - & - & $\mathrm{F}$ & Dissection & - & - & - & - & - & - & - & Yes & - & - \\
\hline [15] & 2010 & - & - & - & - & - & - & - & Yes & Yes & 670 & $\mathrm{~F}$ & Dissection & - & - & - & - & - & - & Yes & Yes & - & - \\
\hline [16] & 2011 & - & - & - & - & - & & & - & - & 31 & $\mathrm{Ce}$ & Dissection & & - & - & - & - & - & No & - & - & - \\
\hline [17] & 2011 & - & - & - & - & PC & - & - & - & - & 141 & F & Dissection & - & - & - & - & - & - & Yes & Yes & Excluded & Coloration \\
\hline$[18]$ & 2011 & - & - & - & - & - & - & - & Yes & - & 120 & $\mathrm{Cr}$ & Dissection & - & - & - & - & - & - & - & Yes & Yes & $\mu \mathrm{R}+\mathrm{SEM}$ \\
\hline [19] & 2011 & - & - & - & - & - & - & - & Yes & - & 182 & F & Dissection & - & - & - & - & - & - & - & Yes & Yes & - \\
\hline [20] & 2012 & - & - & - & - & - & - & - & Yes & - & 569 & F & Dissection & - & - & - & - & - & - & Yes* & Yes & Yes & - \\
\hline [21] & 2012 & - & - & - & - & - & - & - & Yes & - & 425 & F & Dissection & - & - & - & - & - & - & Yes & Yes & - & - \\
\hline [22] & 2013 & - & - & - & - & - & - & - & Yes & - & 595 & F & Dissection & - & - & - & - & - & - & Yes & Yes & - & Density \\
\hline [23] & 2013 & - & - & - & $\mathrm{AFC}$ & - & - & - & Yes & Yes & 388 & F & КОН & $10 \%$ & $3: 1(\mathrm{v} / \mathrm{v})$ & $2-3 \mathrm{w}$ & R.T & - & $200 \mu \mathrm{m}(\mathrm{S})$ & Yes & - & Excluded & FT-IR \\
\hline [24] & 2013 & - & - & - & - & - & - & - & Yes & Yes & 19 & F & Dissection & - & - & - & - & - & - & Yes & Yes & - & - \\
\hline [25] & 2013 & - & - & - & - & - & - & - & - & - & 192 & F & Dissection & - & - & - & - & - & - & Yes & - & - & o \\
\hline [26] & 2013 & n.g. & Yes (S) & - & cws & - & & - & - & - & 504 & F & Dissection & - & - & - & - & - & - & Yes & - & Yes & FT-IR \\
\hline [27] & 2014 & - & Yes (MR) & Yes & $\mathrm{FH}$ & PB (B) & Subtraction & $\mathrm{IA} / \mathrm{B}$ & Part. & Part. & 50 & B & $\mathrm{HNO}_{3}: \mathrm{HClO}_{4}$ & 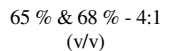 & $5: 1(v / w)$ & O.N & R.T & Yes & $13 \mu \mathrm{m}(\mathrm{C})$ & Yes & Yes & Yes & Hot needle \\
\hline [28] & 2014 & - & - & - & - & - & - & - & Yes & - & Part. & F & Dissection & (VIV) & - & - & - & - & - & Yes & . & Yes & - \\
\hline [29] & 2014 & Yes & Yes (MR) & Part. & $\mathrm{AFC}$ & PB (NC) & - & Nothing & Yes & - & 93 & B & $\mathrm{HNO}_{3}$ & $69 \%$ & $7-25 \mathrm{~mL} /$ indiv & O.N & R.T & Yes & $5 \mu \mathrm{m}(\mathrm{CN})$ & Yes & Yes & Yes & $\mu \mathrm{R}$ \\
\hline [30] & 2014 & - & Yes (R) & - & $\mathrm{FH}$ & $\mathrm{PB}(\mathrm{NC})$ & - & - & Yes & Yes & 50 & B & $\mathrm{H}_{2} \mathrm{O}_{2}$ & $30 \%$ & $15: 1$ à $20: 1(\mathrm{v} / \mathrm{w})$ & - & $55-65^{\circ} \mathrm{C}$ & Yes & $0.8 \mu \mathrm{m}(\mathrm{CN})$ & - & - & Yes & $\mathrm{o}$ \\
\hline [31] & 2015 & - & Yes (MR) & Yes & $\mathrm{AFC}$ & - & - & - & Yes & Yes & 125 & F & $\mathrm{NaCl}+\mathrm{H}_{2} \mathrm{O}_{2}$ & $20.5 \mathrm{M}+15 \%$ & $250 \mathrm{~mL}(\mathrm{NaCl})$ & $10 \min$ & $50^{\circ} \mathrm{C}\left(\mathrm{H}_{2} \mathrm{O}_{2}\right)$ & - & $8 \mu \mathrm{m}(\mathrm{CN})$ & Yes & - & Excluded & FT-IR \\
\hline [32] & 2015 & - & Yes & Yes & $\mathrm{AFC}+\mathrm{FH}$ & PB (B) & Subtraction & - & Yes & Yes & 165 & $\mathrm{Cr}$ & $\mathrm{HNO}_{3}: \mathrm{HClO}_{4}$ & $65 \% \underset{(\mathrm{v} / \mathrm{v})}{68 \%-4: 1}$ & $5: 1(v / w)$ & O.N & R.T & Yes & $13 \mu \mathrm{m}(\mathrm{C})$ & Yes & Yes & Yes & Hot needle \\
\hline [33] & 2015 & - & Yes (MR) & Yes & - & PB & - & $\mathrm{IN} / \mathrm{B}$ & Yes & Yes & 144 & в & $\mathrm{H}_{2} \mathrm{O}_{2}$ & $30 \%$ & $200 \mathrm{~mL}$ & $24 h+24-48 h$ & $65^{\circ} \mathrm{C}+$ R.T & Yes & $5 \mu \mathrm{m}(\mathrm{CN})$ & Yes & Yes & Yes & $\mu \mathrm{F}$ \\
\hline [34] & 2015 & Yes + l.g. & - & - & - & - & & & Yes & Yes & 263 & F & Dissection & - & - & - & - & - & - & Yes & - & Yes & $\mu \mathrm{F}$ \\
\hline [35] & 2015 & - & Yes (MR) & - & - & $\mathrm{AB}$ & Exclusion & $\mathrm{IA} / \mathrm{B}$ & Part. & - & 152 & M & КОН & $10 \%$ & 3:1 (v/v) & O.N & $60^{\circ} \mathrm{C}$ & - & - & Yes & - & Yes & o \\
\hline [36] & 2015 & - & - & - & - & - & - & & Yes & Yes & 22 & F & Dissection & - & - & - & - & - & - & Yes & Yes & - & o \\
\hline [37] & 2015 & - & - & Part. & - & $\mathrm{PB}(\mathrm{NC})$ & - & - & Yes & - & - & B & $\mathrm{HNO}_{3}$ & $69 \%$ & $20 \mathrm{~mL} / 3$ indiv & $0 . \mathrm{N}$ & R.T & Yes & $5 \mu \mathrm{m}(\mathrm{CN})$ & Yes & - & Excluded & $\mu \mathrm{R}$ \\
\hline [38] & 2015 & Yes & Yes (MR) & Yes & $\mathrm{FH}$ & $\mathrm{PB}$ & Exclusion & $\mathrm{IA} / \mathrm{B}(\mathrm{C})$ & Yes & Yes & 425 & В & $\mathrm{HNO}_{3}: \mathrm{HClO}_{4}$ & $65 \% \& 68 \%-4: 1$ & $5: 1(\mathrm{v} / \mathrm{w})$ & $\mathrm{O} . \mathrm{N}$ & R.T & Yes & $13 \mu \mathrm{m}(\mathrm{C})$ & - & Yes & Yes & Hot needle \\
\hline [39] & 2016 & Yes & Yes (R) & - & - & OB & - & Nothing & Yes & - & 212 & F & Dissection + $\mathrm{NaOH}$ & $1 \mathrm{M}$ & $10 \mathrm{~mL}$ & $21 \mathrm{~d}$ & - & - & - & Yes & Yes & Yes & Hot needle \\
\hline [40] & 2016 & Yes + n.g. & Yes $(\mathrm{R}+\mathrm{S})$ & - & RAS & $\mathrm{OB}(\mathrm{B})$ & - & - & - & - & 302 & $\mathrm{~F}$ & Dissection & - & - & - & - & - & - & Yes & Yes & Yes & FT-IR (A) \\
\hline [41] & 2016 & Yes & Yes $(\mathrm{R})$ & - & $\mathrm{FH}$ & $\mathrm{PB}+\mathrm{AB}(\mathrm{NC})$ & - & $\mathrm{IA} / \mathrm{B}$ & Yes & Yes & 54 & в & $\mathrm{HNO}_{3}$ & $69-71 \%$ & $40 \mathrm{~mL}$ & $4 \mathrm{~h}$ & $90^{\circ} \mathrm{C}$ & Yes & $1.2 \mu \mathrm{m}(\mathrm{GF})$ & - & Yes & Yes & 0 \\
\hline [42] & 2016 & - & Yes (MR) & Yes & - & $\mathrm{PB}+\mathrm{PC}$ & - & $\mathrm{IN} / \mathrm{B}$ & S.F & S.F & 390 & B & $\mathrm{H}_{2} \mathrm{O}_{2}$ & $30 \%$ & $200 \mathrm{~mL}$ & $24 \mathrm{~h}+24-48 \mathrm{~h}$ & $65^{\circ} \mathrm{C}+\mathrm{R} . \mathrm{T}$ & Yes & $5 \mu \mathrm{m}(\mathrm{CN})$ & Yes & - & Yes & $\mu \mathrm{F}$ \\
\hline [43] & 2016 & - & Yes $(\mathbf{S})$ & - & - & - & - & - & - & - & 205 & $\mathrm{~F}$ & Dissection & - & - & - & - & - & - & Yes & Yes & Yes & o \\
\hline [44] & 2016 & Yes $+\mathrm{g}$. & Yes (S) & - & CWS & $\mathrm{PB}(\mathrm{NC})+\mathrm{AB}(\mathrm{NC})$ & Exclusion & IN/B (C) & Yes & Yes & 761 & $\mathrm{~F}$ & КОН & $10 \%$ & - & $2 \mathrm{w}$ & - & - & $250 \mu \mathrm{m}(\mathrm{S})$ & Yes & Yes & Yes & o \\
\hline [45] & 2016 & Yes & Yes (R) & - & cws & $\mathrm{OB}+\mathrm{AB}(\mathrm{NC})$ & - & - & Yes & - & 337 & $\mathrm{~F}$ & Dissection & - & - & - & - & - & - & - & - & Yes & - \\
\hline [46] & 2016 & Yes $+\mathrm{g}$. & Yes $(\mathrm{R}+\mathrm{S})$ & - & - & $\mathrm{PB}+\mathrm{AB}(\mathrm{NC})$ & Specif. Subtract. & IN/B (C) & Yes & Yes & 290 & $\mathrm{~F}$ & Dissection & - & - & - & - & - & - & Yes & Yes & Yes & $\mu \mathrm{F}(\mathrm{A})(\mathrm{F})$ \\
\hline [47] & 2016 & Yes & Yes $(\mathrm{R})$ & - & $\mathrm{FH}$ & $\mathrm{OB}(\mathrm{NC})$ & - & - & Yes & - & 30 & B & $\mathrm{HNO}_{3}$ & $22.5 \mathrm{M}$ & - & $0 . \mathrm{N}$ & R.T & Yes & $0.7 \mu \mathrm{m}(\mathrm{GF})$ & - & - & Excluded & PLM \\
\hline [48] & 2016 & - & Yes (H) & - & - & $\mathrm{PB}+\mathrm{AB}(\mathrm{NC})$ & - & $\mathrm{IN} / \mathrm{B}$ & Yes & - & 64 & F & КОН & $10 \%$ & $>3: 1(\mathrm{v} / \mathrm{v})$ & $3-4 d$ & $40^{\circ} \mathrm{C}$ & - & - & Yes & Yes & - & FT-IR \\
\hline [49] & 2016 & - & - & - & - & - & - & - & Yes & - & 1450 & $\mathrm{Cr}$ & Dissection & - & - & - & - & - & - & - & - & Yes & FT-IR \\
\hline [50] & 2016 & - & & - & - & - & - & - & Yes & Yes & 302 & $\mathrm{Cr}$ & Dissection & - & - & - & - & - & - & Yes & Yes & Yes & o \\
\hline [51] & 2017 & n.g. & Yes $(\mathrm{R})$ & - & $\mathrm{AFC}$ & $\mathrm{PB}(\mathrm{NC})$ & - & Nothing & Yes & - & 60 & $\mathrm{~F}$ & $\mathrm{NaClO}+$ Methanol & $9 \%+99 \%$ & - & O.N & - & Yes & $5 \mu \mathrm{m}(\mathrm{CA})$ & Yes & - & Yes & $\mu \mathrm{R}$ \\
\hline [52] & 2017 & Yes & Yes $(M R+S)$ & - & RAS & $\mathrm{PB}(\mathrm{NC})+\mathrm{AB}(\mathrm{NC})$ & - & Dif. from Samp. & - & - & - & B & Trypsin & $0.3125 \%$ & $25 \mathrm{~mL}$ & $30 \min$ & $38-42^{\circ} \mathrm{C}$ & - & $52 \mu \mathrm{m}(\mathrm{G})$ & Yes & Yes & Yes & FT-IR (A) \\
\hline [53] & 2017 & Yes & Yes (R) & - & $\mathrm{AFC}$ & $\mathrm{PB}(\mathrm{NC})+\mathrm{NC}+\mathrm{OC}+$ & Subtraction & Nothing & - & - & 400 & F & Кон & $10 \%$ & $3: 1(\mathrm{v} / \mathrm{v})$ & $2-3 w$ & - & - & $200 \mu \mathrm{m}(\mathrm{S})$ & Yes & Yes & - & FT-IR \\
\hline [54] & 2017 & g. & Yes (S) & - & - & - & - & - & - & - & 76 & F & Dissection & - & - & - & - & - & - & - & Yes & Yes & FT-IR \\
\hline [55] & 2017 & Yes & Yes $(\mathrm{R}+\mathrm{S})$ & - & cws & $\mathrm{AB}(\mathrm{NC})$ & - & - & - & - & 212 & $\mathrm{~F}$ & Dissection & - & - & & - & - & - & Yes & Yes & Yes & $\mu \mathrm{F}$ \\
\hline [56] & 2017 & - & - & - & - & $\mathrm{PB}(\mathrm{NC})$ & - & $\mathrm{IA} / \mathrm{B}$ & Yes & - & 20 & F & Dissection & - & - & - & - & - & - & Yes & Yes & Excluded & $\mu \mathrm{F}$ FT-IR (A) \\
\hline [57] & 2017 & Yes & Yes (MR) & - & Cws & $\mathrm{OB}$ & - & - & Yes & Yes & 417 & $\mathrm{~F}$ & Dissection & - & - & & - & - & - & - & Yes & - & FT-IR \\
\hline [58] & 2017 & Yes + l.g. & - & - & II & PB (B) & Exclusion & - & - & - & 1337 & F & Dissection & - & - & - & - & - & - & Yes & Yes & Yes & FT-IR \\
\hline [59] & 2017 & - & Yes (MR) & Yes & - & $\mathrm{PB}(\mathrm{NC})$ & - & $\mathrm{IA} / \mathrm{B}$ & Yes & Yes & 378 & F & $\mathrm{H}_{2} \mathrm{O}_{2}$ & $30 \%$ & $200-400 \mathrm{~mL}$ & 24 to $72 \mathrm{~h}$ & $65^{\circ} \mathrm{C}$ & Yes & $5 \mu \mathrm{m}(\mathrm{CN})$ & Yes & Yes & Yes & $\mu \mathrm{F}$ \\
\hline [60] & 2017 & Yes + n.g. & Yes (MR) & Yes & $\mathrm{AFC}+\mathrm{CWS}$ & $\mathrm{PB}$ & - & Nothing & Yes & Yes & 120 & F & КОН & $10 \%$ & 10:1(v/w) & $72 \mathrm{~h}$ & $40^{\circ} \mathrm{C}$ & Yes & $149 \& 8 \mu \mathrm{m}$ & - & - & - & $\mu \mathrm{R}$ \\
\hline [61] & 2017 & - & Yes (R) & - & - & PB (B) & Aver. subtract. & $\mathrm{IA} / \mathrm{B}$ & - & S.F & 62 & F & Proteinase K & $3-15 \mathrm{U} / \mathrm{mg}$ & - & $2 \mathrm{~h}+20 \min$ & $50^{\circ} \mathrm{C}+60^{\circ} \mathrm{C}$ & Yes & $1.2 \mu \mathrm{m}(\mathrm{GF})$ & - & Yes & Yes & $\mathrm{o}$ \\
\hline [62] & 2017 & - & Yes $(\mathrm{R})$ & - & - & PB (B) & - & $\mathrm{IA} / \mathrm{B}$ & - & - & 26 & M & $\mathrm{HNO}_{3}$ & - & - & - & - & Yes & $0.7 \mu \mathrm{m}(\mathrm{GF})$ & Yes & Yes & Yes & o \\
\hline [63] & 2017 & - & - & - & $\mathrm{FH}$ & $\mathrm{PB}(\mathrm{NC})$ & Subtraction & - & - & - & 62 & $\mathrm{~F}$ & КОН & $20 \%$ & $3: 1(\mathrm{v} / \mathrm{v})$ & $3 \mathrm{w}$ & R.T & - & $0.7 \mu \mathrm{m}(\mathrm{GF})$ & - & Yes & Yes & o \\
\hline [64] & 2018 & Yes & Yes $(\mathrm{R})$ & Part. & RAS & $\mathrm{PB}+\mathrm{OB}$ & Exclusion & Nothing & Yes & Yes & 120 & F & Dissection + KOH & $10 \%$ & $3: 1(\mathrm{v} / \mathrm{v})$ & $5 \mathrm{~d}$ & $60^{\circ} \mathrm{C}$ & - & $1.2 \mu \mathrm{m}(\mathrm{GF})$ & Yes & Yes & Yes & $\mu \mathrm{F}$ \\
\hline [65] & 2018 & Yes + n.g. & Yes $(\mathrm{R}+\mathrm{S})$ & - & - & - & - & - & Yes & Yes & 148 & $\mathrm{Cr}$ & Dissection & - & - & - & - & - & - & Yes & Yes & Yes & FT-IR (A) \\
\hline [66] & 2018 & - & Yes $(\mathrm{R})$ & - & - & $\mathrm{PB}(\mathrm{NC})$ & Subtraction & - & Yes & Yes & 160 & B & $\mathrm{H}_{2} \mathrm{O}_{2}$ & $30 \%$ & $20: 1(\mathrm{v} / \mathrm{w})$ & - & $55-65^{\circ} \mathrm{C}$ & Yes & $1.2 \mu \mathrm{m}(\mathrm{GF})$ & Yes & Yes & Yes & FT-IR \\
\hline [67] & 2018 & Yes & Yes $(\mathrm{R}+\mathrm{S})$ & - & - & $\mathrm{OB}(\mathrm{B})$ & - & Fibres & Yes & Yes & 72 & $\mathrm{~F}$ & Dissection & - & - & & - & - & - & Yes & Yes & Yes & $\mu \mathrm{F}$ \\
\hline [68] & 2018 & Yes + n.g. & Yes (MR) & Yes & CWS & $\mathrm{PB}$ & - & - & - & - & - & B & КОН & $10 \%$ & $200 \mathrm{~mL}$ & $24 \mathrm{~h}+24 \mathrm{~h}$ & $65^{\circ} \mathrm{C}+\mathrm{R} . \mathrm{T}$ & Yes & $20 \mu \mathrm{m}$ & Yes & Yes & Yes & $\mu \mathrm{F}$ \\
\hline [69] & 2018 & -2 & Yes $(\mathrm{R})$ & Yes & & PB & - & $\mathrm{IN} / \mathrm{B}$ & S.F & S.F & 162 & B & $\mathrm{H}_{2} \mathrm{O}_{2}$ & $30 \%$ & $200 \mathrm{~mL}$ & $24 \mathrm{~h}+24-48 \mathrm{~h}$ & $65^{\circ} \mathrm{C}+\mathrm{R} . \mathrm{T}$ & Yes & $5 \mu \mathrm{m}(\mathrm{CN})$ & Yes & 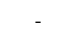 & Yes & $\mu \mathrm{F}$ \\
\hline
\end{tabular}




\begin{tabular}{|c|c|c|c|c|c|c|c|c|c|c|c|c|c|c|c|c|c|c|c|c|c|c|c|}
\hline \multirow[b]{2}{*}{ Ref. } & \multirow[b]{2}{*}{ Year } & \multirow[b]{2}{*}{$\begin{array}{c}\text { Cotton lab } \\
\text { coat }^{\mathrm{a}}\end{array}$} & \multirow[b]{2}{*}{$\begin{array}{c}\text { Cleaning } \\
\text { procedure }^{\mathrm{b}}\end{array}$} & \multirow[b]{2}{*}{$\begin{array}{c}\text { Sol. } \\
\text { filtration }\end{array}$} & \multicolumn{2}{|c|}{ Contamination prevention } & \multirow[b]{2}{*}{$\begin{array}{c}\text { Blanks } \\
\text { management }\end{array}$} & \multirow[b]{2}{*}{ Blank results ${ }^{\mathrm{e}}$} & \multicolumn{4}{|c|}{ Sampling } & \multicolumn{7}{|c|}{ Isolation } & \multicolumn{3}{|c|}{ Quantification } & \multirow{2}{*}{$\begin{array}{c}\text { Identification } \\
\text { Methods }^{\mathrm{m}}\end{array}$} \\
\hline & & & & & $\begin{array}{l}\text { Working } \\
\text { place }^{\mathrm{c}}\end{array}$ & Blanks $^{d}$ & & & $\begin{array}{l}\text { Aver. } \\
\text { Length }\end{array}$ & Aver. weight ${ }^{f}$ & $n^{f}$ & $\underset{\substack{\text { Organism } \\
\mathrm{s}^{\mathrm{g}}}}{ }$ & Method & Concentration & Ratio $^{\mathrm{h}}$ & Time $^{i}$ & $\mathrm{~T}^{\circ} \mathrm{C}^{\mathrm{j}}$ & $\begin{array}{c}\text { Comp. } \\
\text { Treat }\end{array}$ & Filters $^{k}$ & Sizes $^{1}$ & Colors & Fibers & \\
\hline [70] & 2018 & - & - & Yes & - & $\mathrm{PB}(\mathrm{NC})$ & - & Nothing & - & - & 533 & $\mathrm{~F}$ & $\mathrm{KOH}$ & $10 \%$ & $5: 1(\mathrm{v} / \mathrm{v})$ & $24-36 \mathrm{~h}$ & $55^{\circ} \mathrm{C}$ & Yes & $1.6 \mu \mathrm{m}(\mathrm{GF})$ & Yes & - & Yes & $\mu \mathrm{F}$ \\
\hline [71] & 2018 & Yes $+\mathrm{g}$. & Yes $(R)$ & . & - & $\mathrm{PB}+\mathrm{SB}$ & - & Not synthetic & Yes & - & 180 & B & $\mathrm{KOH}$ & $10 \%$ & $50 \mathrm{~mL}$ & $24 \mathrm{~h}$ & $60^{\circ} \mathrm{C}$ & Yes & $12 \mu \mathrm{m}(\mathrm{CN})$ & Yes & Yes & Yes & $\mu \mathrm{F}$ \\
\hline [72] & 2018 & - & Yes $(\mathrm{R})$ & Yes & CWS + RAS & $\mathrm{PB}(\mathrm{B})$ & Specif. Subtract. & $\mathrm{IA} / \mathrm{B}$ & Yes & Yes & 450 & B & $\begin{array}{c}\text { SDS + } \\
\text { Biozym F \& SE }\end{array}$ & $\begin{array}{l}50 \%(5 \mathrm{~g} / \mathrm{L})+25 \% \\
\quad+25 \%\end{array}$ & $6 \mathrm{~mL}$ & $48 \mathrm{~h}$ & $37.5^{\circ} \mathrm{C}$ & - & $20 \mu \mathrm{m}(\mathrm{PN})$ & - & - & Yes & FT-IR \\
\hline [73] & 2018 & - & - & - & & $\mathrm{PB}(\mathrm{NC})$ & - & $\mathrm{IA} / \mathrm{B}$ & - & - & 163 & M & Dissection & - & - & - & - & - & - & - & - & Yes & FT-IR \\
\hline [74] & 2018 & Yes & Yes $(\mathrm{R})$ & - & - & - & - & - & Yes & Yes & 210 & F & Dissection & - & - & - & - & - & - & - & Yes & Yes & FT-IR \\
\hline [75] & 2018 & Yes + n.g. & Yes (MR) & Yes & $\mathrm{AFC}+\mathrm{CWS}$ & $\mathrm{PB}(\mathrm{NC})$ & - & Not synthetic & - & S.F & 198 & $\mathrm{~F}$ & $\mathrm{KOH}$ & $10 \%$ & $10: 1(\mathrm{v} / \mathrm{w})$ & $72 \mathrm{~h}$ & $40^{\circ} \mathrm{C}$ & Yes & $149 \& 8 \mu \mathrm{m}$ & Yes & & Yes & $\mu \mathrm{R}$ \\
\hline
\end{tabular}

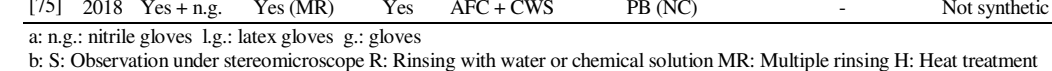

b: : : Obs: Airflow cabinet or assicinilated CWS: Clinged work suffer FH Fumehood RAL: Restricted access laboat treatment

d: PB: Procedural blank AB: Atmosphere blank OB: Observational blank PC: Positive control NC: Negative control SB: storage blank (B): applied per batch (NC): Not communicated number

f: Part: Partially communicated S.F: Communicated in supplementary files

g: F: Fish, Ce: Cephalopods, Cr: Crustaceans, B: Bivalves, M: Multiple organisms
h: Read 3:1 (v/v) as solution added equivalent to 3 t tissue volume and $10: 1$ (v/w) as solution added equivalent to $10 \mathrm{~mL}$ per gram of tissue

i: O.N stands for overnight

J: R.T stands for room temperature
k: : sieve CA: Cellulose acetate CN: Cellulose nitrate C: Cellulose GF: glass fiber PN : Plankton net G:gauze

1: Asterisk materialize a study where weight of MP where communicated instead of size

m: O: Observation of characteristics $\mu R: \mu$-Raman spectroscopy $\mu F$ : $\mu$ FT-IR Fourrier transformed infrared spectroscopy PLM: Polarized Light Microscopy SEM: Scanning Electron Microscopy (A): Attenuated Total Reflectance used (F): Focal Plan Array used 
Table 3

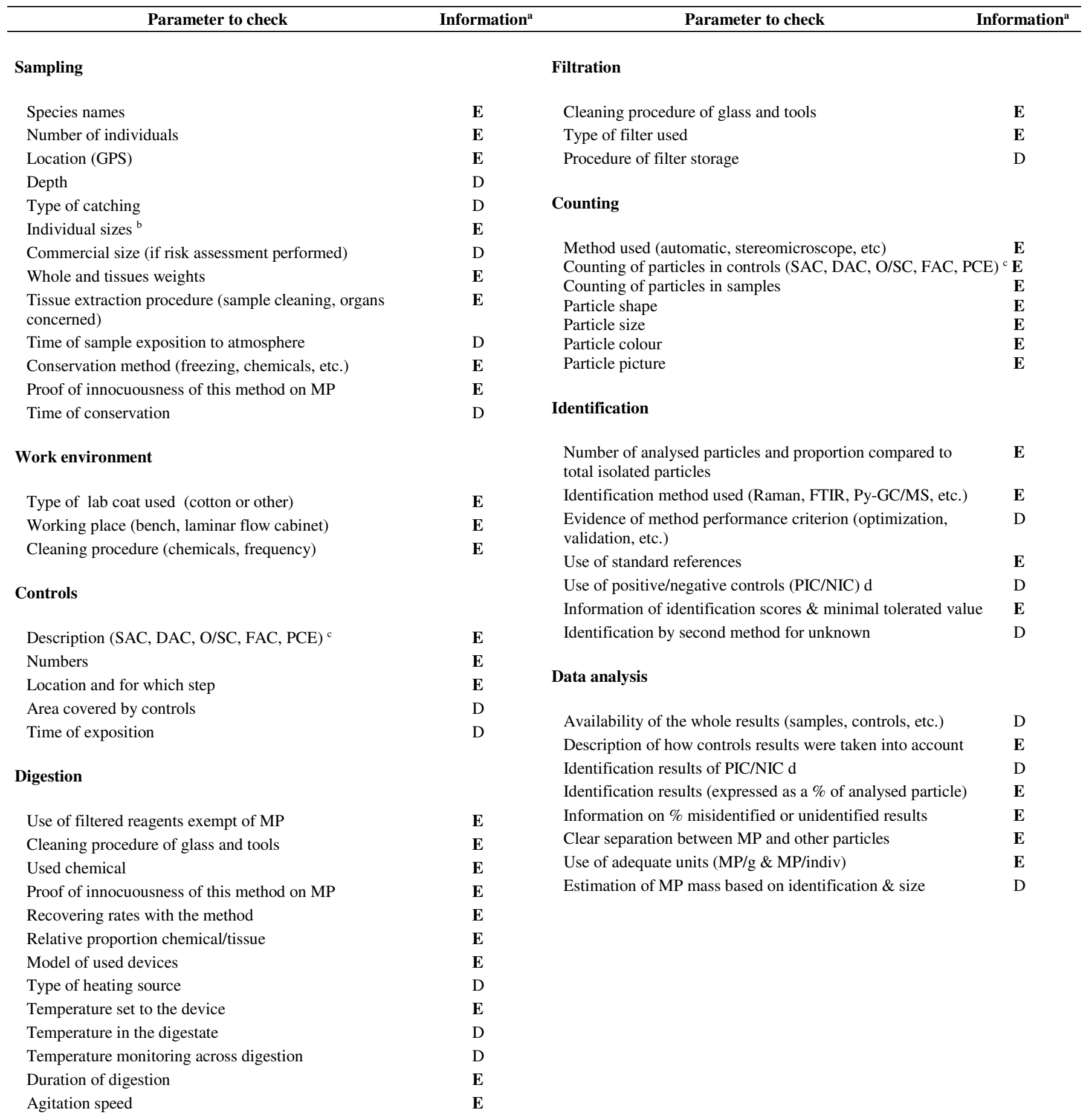

\footnotetext{
${ }^{\mathrm{a}}$ Essential (E) and desirable (D) information for the MP studies

'Based as an example on the Ifremer report "Guide for measuring species in fisheries Fishes, mollusks, shellfishes, marine reptiles, marine mammals" (http://archimer.ifremer.fr/doc/00001/6237/)

${ }^{\mathrm{c}}$ SAC: sampling atmospheric control, DAC: digestion atmospheric control, O/SC: Operator/Solution Control, FAC: filtration atmospheric control and PCE: Positive Control of Extraction

${ }^{\mathrm{d}}$ PIC: Positive Identification Control and NIC: Negative Identification Control
} 
MP (re)definition Standard method(s) 